\title{
İnsanlıktan Uzaklaştırmanın Barış Sürecini Destekleme Niyeti Üzerindeki Etkisi
}

\author{
Ahmet Demirdağ $\breve{g}^{1}$ \\ Ankara Üniversitesi
}

\author{
Derya $\operatorname{Hasta}^{2}$ \\ Ankara Üniversitesi
}

\begin{abstract}
Özet
İnsanlıktan uzaklaştırma kuramı (Leyens ve ark., 2000), insanların iç gruplarına kıyasla dış gruplara insana özgü duyguları (ikincil duygular) daha az atfederek onları insanlıktan uzaklaştırdığını ve bunun dış gruplara yönelik ayrımcı tutum ve davranışlara yol açtığını öne sürmektedir. Bu araştırma kapsamında yürütülen iki deneysel çalışmada, insanlıktan uzaklaştırmanın Kürt sorununa yönelik 2013 yılında başlatılan barış sürecinin desteklenmesi üzerindeki etkisi araştırılmaktadır. İlk çalışmanın $(N=86)$ sonuçları, bir dış grup üyesi tarafından yapılan barış sürecinin desteklenmesi çağrısıyla karşılaştıklarında, Türk ve Kürt katılımcıların bu dış grup üyesine (iç grup üyesine kıyasla) insana özgü duyguları daha az atfettiğini ve Türk katılımcıların (Kürt katılımcıların değil) bu çağrı sonrasında barış sürecini daha az desteklediğini göstermektedir. İkinci çalışmanın $(N=365)$ sonuçları, barış sürecini destekleme çağrısını ikincil duyguları kullanarak yapan bir dış grup üyesinden aldıklarında, hem Türk hem de Kürt katılımcıların dış grup üyesine (iç grup üyesine kıyasla) daha az ikincil duygu atfettiklerini ve bu çağrı sonrasında barış sürecini de daha az desteklediklerini ortaya koymaktadır. Her iki çalışmadan elde edilen bulgular, dış grupları insanlıktan uzaklaştırmanın onların barışa ilişkin çabalarına olan desteği zayıflatabileceğine işaret etmektedir.
\end{abstract}

Anahtar kelimeler: İnsanlıktan uzaklaştırma, ikincil duygular, birincil duygular, barış süreci, gruplar arası barış, Kürt sorunu

\begin{abstract}
According to infrahumanization theory (Leyens et al., 2000), people tend to infrahumanize outgroups through attributing more uniquely human emotions (i.e., secondary emotions) to their ingroups than to outgroups, which in turn results in discriminatory attitudes toward outgroups. In the current research, two experiments were conducted to explore the effect of infrahumanization on the support for the peace process initiated in 2013 regarding the Kurdish Question in Turkey. In the first study $(N=86)$, results revealed that Turkish and Kurdish participants associated the outgroup with uniquely human emotions less than the ingroup and the Turkish participants (but not the Kurdish participants) expressed less support for the peace process when they confronted with a pro-peace call from the outgroup. In the second study $(N=365)$, the results showed that both Turkish and Kurdish participants attributed less uniquely human emotions to the outgroup than the ingroup and supported the peace process less when the pro-peace call was expressed using uniquely human emotions by the outgroup. Overall, the results from both studies suggest that infrahumanization of outgroups can weaken the willingness to support outgroup initiated intergroup peace efforts.
\end{abstract}

Keywords: Infrahumanization, secondary emotions, primary emotions, peace process, intergroup peace, Kurdish question

Yazar notu: Bu çalışma, ilk yazarın yüksek lisans tezine dayanmaktadır.

Yazışma Adresi: ${ }^{1}$ Arş. Gör. Ahmet Demirdağ, Ankara Üniversitesi, Dil ve Tarih-Coğrafya Fakültesi, Psikoloji Bölümü, 06100 Sıhhiye, Ankara, ahmetdemirdagg@gmail.com, ORC-ID: 0000-0002-1288-4830

${ }^{2}$ Doç. Dr., Ankara Üniversitesi, Dil ve Tarih-Coğrafya Fakültesi, Psikoloji Bölümü, dhasta@ankara.edu.tr, ORC-ID: 0000-0002-6299-0666

Gönderim Tarihi: 28.11 .2018

Kabul Tarihi: 28.11 .2020 
Sert ve uzun süren gruplar arası çatışmaların resmi düzeyde sonlandırılması, bu çatışmaların kalıcı bir şekilde bitirilmesini sağlayamamaktadır. Resmi barış süreçlerinin kalıcı barışa evrilebilmesi için toplumsal düzeyde de benimsenmesi gerekmektedir (Bar-Tal, 2000). Bu gerçekle uyumlu olarak, Türkiye'de yaşanan Kürt sorununa çözüm bulmak için 2013 yılında başlatılan 'barış süreci'nin soruna hem resmi düzeyde çözüm bulmayı hem de bu çözüm etrafında toplumsal uzlaşma sağlamay1 amaçladığı söylenebilir. Örneğin, hükümet bir taraftan PKK ve Kürt siyasi hareketinin temsilcileriyle müzakereler yürütürken, bir taraftan da 'akil insanlar' heyeti aracılığıyla toplumu bu sürece ikna etmeye çalışmıştır (Aljazeera, 2013; Milliyet, 2013; Seta, 2013). Bununla birlikte, o dönemde yapılan kamuoyu araştırmaları toplumun azımsanmayacak bir kısmının barıș sürecine karşı çıktığını göstermektedir (Bilgesam, 2013; Habertürk, 2013; T24, 2013).

Barış sürecini destekleme konusundaki söz konusu toplumsal ayrışma hangi psikolojik etmenlerle ilişkilidir? Kürt sorunu on yıllardan bu yana Türkiye'nin en önemli meselelerinden biri olmasına karşın, bu sorunun cevabını Türkiye'de yapılan psikoloji çalışmalarında bulmak kolay değildir. Türkiye'de yapılan psikoloji araştırmaları, yakın zamana kadar bir tabu olarak görülen bu sorunu görmezden gelmiş görünmektedir (Göregenli, 2010). Oysaki benzer gruplar arası çatışma bağlamlarında-Kuzey İrlanda, Güney Afrika ve İsrail-Filistin gibi-bu konularda zengin bir psikoloji yazının olduğu görülmektedir (bkz. Bar-Siman-Tov, 2004; Nadler, Malloy ve Fisher, 2008a). Kuşkusuz, Kürt sorununun ve ona ilişkin çözüm çabalarının psikolojik etmenler açısından daha çok incelenmesi sorunun hem daha iyi anlaşılmas1na hem de daha etkili ve doğru politikaların üretilmesine katkıda bulunacaktır.

Buradan hareketle, mevcut araştırma barıș sürecini destekleme konusundaki toplumsal ayrışmayı sosyal psikolojik açıdan ele almayı amaçlamaktadır. Uzun yıllara yayılan gruplar arası çatışmalarda, yaşananlardan tamamen karşı tarafin sorumlu tutulması (Noor, Shnabel, Halabi ve Nadler, 2012), uğranılan zarardan dolay1 iç grubun kimlik saygısının zedelenmesi ve bunu telafi etme ihtiyacı (Nadler ve Saguy, 2004) ve olayların çatışmacı bir bakış açısıyla değerlendirilmesi (Bar-Tal ve Bennink, 2004) gibi tarafların barışı desteklemesini güçleştiren çeşitli sosyal psikolojik etmenler ortaya çıkabilmektedir. Bununla birlikte araştırmalar, tarafların birbirine aynı düzeyde insanlık atfetmesinin, diğer bir deyişle, birbirini insanlıktan çıkarmamasının (Bar-Tal,
1989; Haslam, 2006; Leyens ve ark., 2000) barışın önündeki bu zorlukları aşmaya yardımcı olabileceğine de işaret etmektedir (Kelman, 2008; Tam ve ark., 2007, 2008; Wohl ve Branscombe, 2005). Bu araştırma kapsamında yürütülen iki ayrı çalışmada, barış sürecini destekleme konusundaki toplumsal ayrışmada insanlıktan uzaklaştırmanın ${ }^{1}$ (infrahumanization; Leyens ve ark., 2000) rolü incelenmektedir. İlk çalışmada, barış sürecinin desteklenmesini isteyen diş grup üyelerinin insanlıktan uzaklaştırılması ve barış sürecini desteklemeye yönelik etkinliklerin desteklenmesi arasındaki ilişki incelenmektedir. İkinci çalışmada, insanlıktan uzaklaştırma ve barış sürecini destekleme değişkenleri arasındaki ilişki, barış sürecinin desteklenmesine ilişkin isteklerini insana özgü niteliklerini ön plana çıkararak dile getiren dış grup üyeleri bağlamında incelenmektedir.

\section{Insanlıktan Uzaklaştırma}

İnsanlıktan uzaklaştırma kuramına göre (Leyens ve ark., 2000, 2003), insanlar iç gruplarının dıș gruplardan daha fazla insani öz taşıdığına inanmaktadırlar. Kurama göre, ayrıca, bazı duygular da dil, zeka ve kültür gibi insanı diğer canlılardan (örn., hayvanlardan) ayırt edebilme potansiyeline sahiptir. Bu nedenle insanlar, insan ve diğer canlılardaki ortak özü yansıtan duyguları (birincil duygular; şaşırma, iğrenme ve arzu gibi) iç ve diş gruba atfetmede herhangi bir yanlılığa başvurmazken sadece insandaki özü yansıtan duyguları (ikincil duygular; hayranlık, umut ve suçluluk gibi) iç gruba daha çok atfetme eğilimindedirler (örn., Demoulin ve ark., 2004, 2009; Leyens ve ark., 2001). İç grubu diş gruptan daha üstün bir konuma yükselterek iç grup lehine insani bir hiyerarşi tesis eden bu yanlılık (dış gruba oranla iç gruba daha çok ikincil duygu atfetme yanlılığı) insanlıktan uzaklaştırma olarak adlandırılmaktadır.

İnsanlıktan uzaklaştırma kuramının birincil ve ikincil duygu ayrimı temel evrensel duygular ve sonradan edinilen duygular ayrımına dayanmaktadır (örn., Ekman, 1992; Izard, 1972; Stein ve Oatley, 1992). Bu ayrıma göre, birincil duyguların doğuştan getirilmiş olmaları, kültürden bağımsız olmaları, diğer canlılarda da bulunabilmeleri ve genellikle tepkisel olarak ortaya çıkmaları gibi temel özellikleri vardır. İkincil duyguların en temel özelliği ise sonradan öğrenilmiş olmalarıdır. Dolayısıyla, bu duygular yaşamın sonraki yıllarında ortaya çıkan, yoğunlukları az olan, bilişsel ve ahlaki boyutları bulunan ve tepkisel olmayan duygular olarak tanımlanmaktadır (Demoulin ve ark., 2004; Leyens ve ark., 2000).

1 Infrahumanization kavramının Türkçe karşılığı için "alt insanlaştırma”, "insandan aşağıda görme”, "yeterince insan görmeme” gibi başka karşılıklar da düşünülebilir. Ancak insanlıktan uzaklaştırma kuramının yazarları subhumanization kavramını kullanmaktan özenle kaçınmışlar ve çalışmalarında bu iki kavramı birbirinin yerine hiç kullanmamışlardır. Benzer şekilde, bu çalıșmada da kavram için "alt insanlaștırma" gibi bir karşılık tercih edilmemiștir. Onun yerine, hem iç grup sevgisini hem de dıș grup nefretini aynı anda barındıran bu eğilim için (infra ön ekinin bașına geldiği sözcüklere "ötede", "beride", "ileride" anlamlarını katabildiği de düşünülerek) insanlıktan uzaklaştırma karşılığı tercih edilmiştir. 
Bilimsel yazındaki bu ayrım sıradan insanların zihninde de mevcuttur. Örneğin, insanlar ikincil duygularla ilgili yukarıda bahsi geçen özellikleri birincil duygulardan çok ikincil duygulara atfetmekte ve ikincil duyguları hayvansal bir bağlamdan çok insani bir bağlamla ilişkilendirmektedir (Demoulin ve ark., 2004). İnsanların zihninde de duyguların insani özü yansıtan ve yansıtmayan olarak ikiye ayrılması, insani özü yansıtan duyguların (ikincil duygular) dış gruba oranla iç gruba daha fazla atfedilmesini açıklamaktadır.

İç gruba kıyasla dış gruplara daha az ikincil duygu yakıştırıldığını, bu yolla dış grupları insanlıktan uzaklaştırmaya başvurulduğunu gösteren kapsamlı bir yazın bulunmaktadır (bkz. Leyens, Demoulin, Vaes, Gaunt ve Paladino, 2007; Vaes, Leyens, Paladino ve Miranda, 2012). Bu eğilim yalnızca pozitif ikincil duyguların (örn., hayranlık, gurur, umut) atfı yoluyla değil, negatif ikincil duyguların (örn., hayal kırıklığı, hor görme, suçluluk) atfı yoluyla da olmaktadır (örn., Cuddy, Rock ve Norton, 2007; Paladino ve ark., 2002; Vaes, Paladino ve Leyens, 2006; Wohl, Hornsey ve Bennett, 2012). Ek olarak, insanlar yalnızca iç gruplarına daha çok ikincil duygu atfetmekle kalmamakta, diş gruba ikincil duygu atfetmekte isteksiz de davranmaktadır (Demoulin ve ark., 2005; Gaunt ve ark., 2002; Leyens ve ark., 2001). Bu bulgular, insanlıktan uzaklaştırma eğiliminin sadece iç grup kayırmacılığını (ingroup favoritism) değil, dış grup değersizleştirmesini de (outgroup derogation) içerdiğini göstermektedir (Leyens ve ark., 2003, 2007). Ayrıca bu eğilim, grup statüsünden bağımsız olarak işlemektedir. Alt gruplar da üst gruplar kadar insanlıktan uzaklaştırmaya başvurabilmektedir (Leyens ve ark., 2007). Grup statüsünden bağımsız olarak, iç grup insani hiyerarşide en üst basamağa çıkarılırken dış grupların alt basamaklara doğru itilmesi eğilimi gruplar arası ayrımcılığı beraberinde getirmektedir (Leyens ve ark., 2001).

\section{İnsanlıktan Uzaklaştırma ve Gruplar Arası İlişkiler}

Sosyal gruplar birbirlerini insanlıktan uzaklaştırdıkça (birbirine daha az ikincil duygu atfettikçe) birbirini daha itici bulmakta ve bu nedenle birbirine daha olumsuz davranmaktadır. İlk olarak, bir grubun ne kadar insani öz taşıdığına ilişkin inanç (örn., Cuddy ve ark., 2007; Wohl ve ark., 2012) ya da bilgi (örn., Pereira, Vala ve Leyens, 2009) o gruba yönelik davranışları etkilemektedir. Örneğin, dış grubun ikincil duyguları yaşama kapasitesi yetersiz algilanıyorsa ya da biliniyorsa o gruba daha az yardım edilmekte (Cuddy ve ark., 2007), daha az inanılmakta (Wohl ve ark., 2012), o grubun insana özgü ihtiyaçlarını görmezden gelme kolaylaşmakta (DeLuca-McLean ve Castano, 2009) ve o grubun iç grubun ayrıcalıklarından faydalanmasına daha olumsuz yaklaş1lmaktadır (Pereira ve ark., 2009).
İkinci olarak, dış grup üyelerinin ikincil duyguları kullanması onların daha az insan olarak algılanmalarıyla sonuçlanmaktadır (Vaes ve ark., 2006). Bu nedenle, diş grup üyeleri isteklerini birincil duygularla ifade ettiklerinde iç gruba verilen tepkilere benzer tepkilerle karşılaşırlarken, ikincil duygularla ifade ettiklerinde olumsuz ya da hoş olmayan tepkilerle karşılaşmaktadırlar. Örneğin, kendini ikincil duygularla ifade eden dış grupların yardım istekleri daha nahoş karşılanmakta, fikir ve bakış açılarının benimsenmesi ya da anlaşılması daha zor olmakta; kaçınmacı tepkilerle karşılaşmaları ise daha kolay olmaktadır (Vaes, Paladino, Castelli, Leyens ve Giovanazzi, 2003; Vaes, Paladino ve Leyens, 2004; Vaes, Paladino ve Magagnotti, 2011). Buna karşın, bu çalışmalarda birincil duyguların ikincil duyguların aksine iç ve dış gruba yönelik tutum ve davranışlarda bir farklılığa yol açmadığı görülmektedir.

\section{İnsanlıktan Uzaklaştırma ve Gruplar Arası Barış}

Bar-Tal'a göre (1998, 2000), gruplar arası çatışmaların uzun yıllara yayılması çatışmaları besleyen bir değerler sistemini (ethos of conflict: iç grubun tamamen iyi ve haklı dış grubun ise tamamen kötü ve haksız olmas1, çatışmanın sıfir toplamlı bir süreç olarak görülmesi gibi) beraberinde getirmektedir. Bu çatışmacı değerler zaman içinde çatışmaya ilişkin inanç, motivasyon ve davranışları şekillendirerek grupların kolektif hafızasını bu doğrultuda değiştirmektedir. Bu ise bir yandan çatışmaların tek taraflı olarak değerlendirilmesine yol açarak tarafların çatışmaya bakışını katılaştırırken, bir yandan da gruplar arası kin, nefret ve önyargıları artırmaktadır. Bu nedenle, eskinin (olumsuz) etkisinden kurtulmak zorlaşmakta ve barış sağlandıktan yıllar sonra bile çatışma olasılığı tamamen ortadan kalkamamaktadır (Bar-Tal, 2000; Shnabel ve Nadler, 2008).

Kalıcı bir barışın sağlanabilmesi için barış süreçlerinin toplumun tamamı ya da çoğunluğu tarafından benimsenmesinin ve çatışmacı değerlerin gruplar arası barış ve anlayışı destekleyen değerlerle (kabul, affetme ve güven gibi) ikame edilmesinin önemine dikkat çekilmektedir (Bar-Tal, 1998, 2000; Bar-Tal ve Bennink, 2004; Shnabel ve Nadler, 2008). Bu doğrultuda, tarafların çatışmalar boyunca zedelenen güvenlik, adalet, sayg1 görme ve mağduriyetlerinin tanınması gibi ihtiyaçlarının karşılıklı olarak kabul edilmesi önem arz etmektedir (Nadler, Malloy ve Fischer, 2008b; Nadler ve Saguy, 2004; Noor ve ark., 2012). Bunun için ise tarafların birbirinin insanlığını karşılıklı olarak kabul etmesinin (Kelman, 2008), karş1 grubun gayrimeşrulaştırılmasına (delegitimization; Bar-Tal, 1989) son verilmesinin (BarTal, 2000) ve dış gruba iç grupla aynı düzeyde insanlık atfedilmesinin (Tam ve ark., 2008; Wohl ve Branscombe, 2005) önemine vurgu yapılmaktadır. 
Nitekim, Kuzey İrlanda ve eski Yugoslavya gibi uzun yıllara yayılmış gruplar arası sert çatışmaların yaşandığ düzeyi arttıkça (insanlıktan uzaklaştırma düzeyi azaldıkça) onu affetme (Tam ve ark., 2007, 2008) ve onunla empati kurma (Cehajic, Brown ve Gonzalez, 2009) eğilimi artmakta, geçmişte yaşanılan acılardan dolayı onu suçlama eğilimi ise azalmaktadır (Andrighetto ve ark., 2012). Benzer şekilde, ikincil duyguların atfındaki isteksizlik iç gruba zarar veren dış gruplara yönelik güven ve empati duygularını azaltarak onların özrünün kabul edilmesini zorlaştırmaktadır (Wohl ve ark., 2012).

$\mathrm{Bu}$ çalışmalar, insanlıktan uzaklaştırmanın gruplar arası çatışmaları sonlandırmada engelleyici bir role sahip olduğunu göstermektedir. Mevcut çalışmanın temel amacı insanlıktan uzaklaştırmanın bu engelleyici rolünü 2013 yılındaki barış süreci bağlamında test etmektir.

\section{Mevcut Araştırma ve Hipotezler}

Kürt Sorunu kaynaklı çatışma ve şiddet ortamının neden olduğu can kayıpları, maddi zararlar ve diğer mağduriyetler (bkz. Konda, 2011) toplumsal ve siyasi kutuplaştırmayı arttırarak Türk ve Kürt milliyetçiliğini yükseltmiştir (Kirişçi ve Winrow, 2011). Zaman içinde bu iki milliyetçiliğin birbirini beslemesi ise taraflar arasındaki gerilimi, tehdit algısını ve ötekileştirmeyi giderek arttırmıştır (Ensaroğlu ve Kurban, 2011; Kentel, Ahıska ve Genç, 2009; Saraçoğlu, 2009). Türkiye'nin doğusunun ve batısının bu sosyo-politik atmosferde oluşan ön kabuller üzerinden birbirini tanımlaması ise kaçınılmaz olarak toplumsal ayrışma ve çatışmanın derinleşmesini beraberinde getirmiş görünmektedir.

Söz konusu sosyo-politik koşulların her iki grubun birbirini insanlıktan uzaklaştırması için uygun bir zemin oluşturduğu söylenebilir. Yukarıda özetlenen yazından da anlaşılabileceği gibi, gruplar birbirlerini insanlıktan uzaklaştırmaya ne kadar çok başvurursa birbirlerine anlayış göstermeye ve aralarındaki çatışmalara son vermeye o ölçüde isteksiz olmaktadır. İnsanlıktan uzaklaştırmanın gruplar arası çatışmalardaki bu rolü, onun barış sürecini desteklemeye yönelik niyet ya da tutumları da olumsuz yönde etkileyebileceğini göstermektedir. Gruplar arası çatışmaların insanlıktan uzaklaştırma eğilimini artırıcı bir etkiye sahip oluşu da (Leyens ve ark., 2007) bu çıkarımı desteklemektedir.

$\mathrm{Bu}$ arka plandan hareketle, ilk çalışmada, kendisini Türk ya da Kürt olarak tanımlayan katılımcıların barış sürecinin desteklenmesini isteyen bir iç ve dış grup üyesini insanlıktan uzaklaştırma düzeyi ile bu kişinin barış sürecini desteklemeye yönelik etkinliklerini destekleme düzeyi arasındaki ilişki incelenmektedir. Barış sürecinin desteklenmesini isteyen kiși dış grup üyesi olduğunda ona daha az ikincil duygunun yükleneceği ve bu nedenle onun barış sürecini desteklemeye yönelik etkinliklerinin daha az destek bulacağı beklenmektedir. Barış çağrısını yapan iç grup ve dış grup üyesine yüklenecek birincil duygu düzeyinde ise herhangi bir farklılık beklenmemektedir. İkinci çalışmada, aynı barış sürecini destekleme çağrısının birincil ya da ikincil duygular kullanılarak yapılmasının insanlıktan uzaklaştırma ve barış sürecine yönelik etkinliklerin desteklenmesi üzerindeki etkisi incelenmektedir. Bir dış grup üyesi barış sürecinin desteklenmesi çağrısını ikincil duyguları kullanarak yaptığında ona iç grup üyesine oranla daha düşük düzeyde ikincil duygu atfedilmesi ve onun barış sürecini desteklemeye yönelik etkinliklerinin de iç grup üyesininkine göre daha az desteklenmesi beklenmektedir. Ancak, barış çağrısı birincil duygular kullanılarak yapıldığında iç grup ve dış grup arasındaki bu farkların oluşmayacağı öngörülmektedir.

\section{Çalışma 1}

İç gruba oranla diğer grupların ikincil duygular1 yaşama kapasitesinin daha az olduğuna inanılması o gruplara yönelik tutum ve davranışların olumsuzlaşmasıyla sonuçlanabilmektedir (örn., Cuddy ve ark., 2007; örn., Pereira ve ark., 2009; Wohl ve ark., 2012). Bu bilgiler ışığında, bu çalışma, aşağıdaki iki hipotezi test etmeyi amaçlamaktadır:

1. Barış sürecinin desteklenmesini isteyen kişi dış grup üyesi olduğunda ona (iç grup üyesi olduğu duruma kıyasla) daha az ikincil duygu yüklenecek ve onun barış sürecini desteklemeye yönelik olarak önerdiği etkinlikler daha az destek bulacaktır.

2. Barış sürecini destekleme çağrısının bir iç grup ya da dış grup üyesi tarafından yapılmış olması iç grup ve dış grup üyesine atfedilecek birincil duygu düzeyinde bir farklılaşmaya yol açmayacaktır.

\section{Yöntem}

\section{Örneklem}

Çalışmanın örneklemi Ankara ve Mardin'deki üniversitelerde eğitim gören 86 lisans öğrencisinden oluşmaktadır (yaş aralığı: 19-34 (Ort. $=21.55, S=2.93) ; 42$ Kürt (\%49), 44 Türk (\%51); 59 kadın (\%69), 25 erkek (\%30), iki kişi cinsiyetini belirtmemiştir).

\section{Veri Toplama Araçları Manipülasyon Düzenlemeleri}

Çalışmada katılımcılara barış sürecinin desteklenmesine ilişkin 120 sözcükten oluşan bir çağrı metni okutulmuştur. Metinde çağriyı yapan kişi, ilk olarak, Kürt sorunuyla ilişkili 30 yıllık şiddet ortamını kısaca hatırlatmakta ve barış sürecini destekleyici etkinlikler yapmak isteyen gönüllü bir grubun üyesi olduğunu belirtmekte- 
dir. Daha sonra ise metni okuyan kişiden etkinliklerine destek vermesini istemektedir (bkz. Ek 1).

Veriler 2 (katılımcının grubu: Türk-Kürt) X 2 (çağrıyı yapanın grubu: Türk-Kürt) faktöriyel desenine uygun olarak toplanmıştır. Deneyde barış çağrısını yapanın etnik kimliği Türk ve Kürt olarak değiştirilerek iç grup-dış grup manipülasyonu yapılmıştır. İç grup ve dış grup manipülasyonu için, katılımcılara çağrı metnini okumadan önce bir yönerge verilmiştir. Yönergede, ilk olarak, katılımcılardan okuyacakları metnin, kendisini Türk (Kürt) olarak tanımlayan biri tarafından kendilerine hitaben yazıldığını düşünmeleri istenmiştir. Vurgu amacıyla Türk ve Kürt sözcüklerinin altı çizilmiştir. Ardından çağrı metninin tamamını dikkatlice okumaları istenmiştir. Katılımcıların iç grup-dış grup koşullarına seçkisiz ataması ise şu şekilde yapılmıștır: İlk olarak, koşullar birden dörde kadar (01, 02, 03, 04 biçiminde) numaralandırılmış ve koşul başına 30 adet anket formu hazırlanmıştır (hücre başına en az 25 katılımcıya ulaşma hedefiyle). Sonrasında, seçkisiz bir sayı tablosu (random number table) üzerinde koșul numaraları 30'ar kez seçilmiş ve seçilme sırasına göre numaralandırılmıștır. Anket formları bu sıraya göre sıralanarak sınıf ortamında kat1lımcılara dağıtılmıştır.

Deneyin diğer değişkeni olan katılımcıların etnik kökeni, demografik bilgi formunda sorulan etnik köken sorusu yardımıyla belirlenmiştir. Katılımcılar demografik bilgi formunu deneyin en son aşamasında doldurmuşlardır. Bu formda etnik kökenini Türk veya Kürt olarak belirtmeyen katılımcılar analizlere dâhil edilmemiştir.

\section{Bağımlı Değișkenler}

Çalışmanın bağımlı değişkenlerinden olan birincil ve ikincil duygu düzeylerini ölçmek için İnsanlıktan Uzaklaştırma Ölçeği kullanılmıştır. Çalışmanın diğer bağımlı değişkeni olan, barış sürecini destekleme çağrısını yapan kişinin barış sürecini desteklemeye yönelik olarak önerdiği etkinlikleri destekleme düzeyini belirlemek içinse Barış Sürecini Destekleme Ölçeği kullanılmıştır. Her iki ölçek de bu araştırma kapsamında gerçekleştirilen bir ön çalışmada geliştirilmiştir. Ön çalışmanın katılımcıları 180 lisans öğrencisinden oluşmuştur (yaş aralığı: 18-42 (Ort. $=22.31, S=4.15) ; 113$ kadın $(\% 63)$, 67 erkek (\%37); 131 Türk (\%73), 34 Kürt (\%19), 14 diğer etnik kimlikler (\%8), bir kişi etnik kimliğini belirtmemiştir). Ölçekler için elde edilen geçerlik güvenirlik bilgileri izleyen başlıklar altında sırasıyla özetlenmiştir.

\section{Ínsanlıktan Uzaklaştırma Ölçeği}

Ölçek ilgili yazından (Demoulin ve ark., 2004; Leyens ve ark., 2001; Vaes ve ark., 2003) derlenen 40 adet duygu arasından, insana özgülük ve olumluluk düzeyleri temel alınarak seçilen 12 duygudan oluşmaktadır.
Şöyle ki, ilk olarak, katılımcılar bu 40 duyguyu insana özgülük ( 1 = hem insan hem hayvanlarda bulunur, $7=$ sadece insanda bulunur $)$ ve olumluluk (1 = tamamen negatif bir duygudur, 7 = tamamen pozitif bir duygu$d u r)$ düzeyleri açısından puanlamıştır. İkinci adımda, bu puanlar temel alınarak altı birincil duygu (üç pozitif ve üç negatif, sırasıyla: şaşırma, şefkat, sakin olma; panik, öfke, sinirlenme) ve altı ikincil duygu (üç pozitif ve üç negatif, sırasıyla: aşk, halden anlama, geçmişe özlem duyma; melankoli, içerlenme, suçluluk) seçilmiştir. Bağımlı $t$ testi analizi yapılarak, seçilen birincil ve ikincil duyguların insana özgülük düzeyi açısından birbirinden farklılaşması ama olumluluk düzeyi açısından birbirine denk olması sağlanmıştır. Daha açık bir ifadeyle, pozitif ikincil duyguların pozitif birincil duygulardan anlamlı olarak daha insana özgü algılanmış olmasına ama bu iki duygu grubunun olumluluk düzeyi açısından birbirine denk olarak algılanmış olmasına dikkat edilmiştir. Benzer şekilde, negatif ikincil duyguların negatif birincil duygulardan anlamlı olarak daha insana özgü algılanmış olmasına ama bu iki duygu grubunun olumluluk düzeyi açısından birbirine denk olarak algılanmış olmasına dikkat edilmiştir. Böylece, bu ölçek aracılığıyla iç grup ve dış gruba atfedilecek birincil ve ikincil duygu düzeyinde ortaya çıkacak bir farklılaşmanın olumluluk yanlığından değil, insana özgülük düzeyindeki farlılıktan kaynaklandığı söylenebilecektir. Üçüncü adımda, yapılan temel bileşenler analizi söz konusu 12 maddeden altısının ikincil duygu faktörü altında (özdeğer: 3.57; açıklanan varyans: \%26.03; faktör-yük aralığı: .59-.77; $\alpha$ : .80) diğer altıs1nın ise birincil duygu faktörü altında toplandığını ortaya koymuştur (özdeğer: 2.42; açıklanan varyans: \%23.87; faktör-yük aralığı: .42-.78; $\alpha$ : .76). Mevcut çalışmada ise birincil ve ikincil duygu alt testlerinin Cronbach alfa iç tutarlılık katsayıları $(\alpha)$ sirasıyla .63 ve .62 olarak hesaplanmıştır (bu değerler, güvenirlik düzeyini düşürdükleri için birincil duygu alt testinden sakin olma, ikincil duygu alt testinden ise melankoli duygusu çıkarıldıktan sonra hesaplanmıştır. Maddeler çıkarılmadan önceki alfa değerleri $(\alpha)$ sirasıyla, .57 ve .59'dur).

Katılımcılar barış sürecini destekleme çağrısı yapan kişinin bu duyguları ne kadar taşıdığını 1 ( hiç taşımıyor) ile 7 (çok taşıyor) arasında değerlendirmiştir. İkincil duygu alt testinden alınan puanlar azaldıkça insanlıktan uzaklaştırma düzeyi artmaktadır. Birincil duygu alt testinden alınan puanlar ise insanlıktan uzaklaştırma düzeyini yansıtmamaktadır; bu alt test ikincil duygularla karşılaştırma yapmak amacıyla kullanılmıştır.

\section{Barış Sürecini Destekleme Ölçeği}

Ölçek, barış sürecini desteklemeye yönelik davranışsal niyetleri ifade eden beş maddeden oluşmaktadır: 'Barış sürecini destekleyen grup veya organizasyonların 
etkinliklerine katılmak ${ }^{2}$, 'Barış sürecini destekleyen bir imza toplama kampanyasında etkin olarak rol almak', 'Türkiye Büyük Millet Meclisi'ne barış sürecini destekleyen bir e-posta göndermek', 'Barış sürecini savunan bildiriler dağıtmak', 'Facebook ve Twitter gibi sosyal medya platformlarındaki tartışmalarda barış sürecini savunan yorumlar yazmak.' İlk üç madde Pereira ve arkadaşlarının (2009) ayrımcılık ölçeğinden barış süreci bağlamına uyarlanmıştır. Son iki madde ise araştırmacılar tarafından yazılmıştır. Temel bileşenler analizi sonuçlarına göre maddeler tek bir faktör altında toplanmaktadır (özdeğer: 4.23; açıklanan varyans: \%84.60; faktör yük aralığ1: .89-.94; $\alpha$ : .95). Ölçeğin mevcut çalışmada hesaplanan Cronbach alfa iç tutarlılık katsayısı ise $\alpha=.94$ 'tür. Katılımc1lar maddeleri 1 (kesinlikle hayır) ile 7 (kesinlikle evet) arasında değişen bir ölçek üzerinde değerlendirmiştir. Yönergede, katılımcılardan ölçek maddelerindeki davranışların barış sürecinin desteklenmesi çağrısı yapan kişi tarafindan kendilerinden istendiğini düşünmeleri ve buna göre ölçek maddelerine katılma düzeylerini belirtmeleri istenmiştir. Maddelerden alınan puanlar arttıkça barış sürecini destekleme niyeti de artmaktadır.

\section{Demografik Bilgi Formu}

Demografik Bilgi Formunda katılımcılardan etnik köken, yaş, cinsiyet vb. konularda bilgi vermeleri istenmiştir. Katılımcılar deneyin en son aşamasında demografik soruları yanıtlamışlardır. Etnik köken bilgisi, katılımcıların etnik kökeni değişkenini belirlemek için kullanılmıştır. Bu nedenle, etnik kökenini Türk veya Kürt olarak belirtmeyen katılımcılar analizlere dâhil edilmemiştir.

\section{İşlem}

Veriler 2014 yılının Mart ve Mayıs ayları arasında, barış süreci devam ederken toplanmıştır. Verilerin toplanması, sınıf ortamında araştırmacılar tarafından gerçekleştirilmiştir.

Bilgilendirilmiş onamın ardından, katılımcılar iç grup ve dış grup koşullarına seçkisiz olarak atanmıştır (seçkisiz atamanın ayrıntıları için yukarıda, "manipülasyon düzenlemeleri” başlığı altındaki bilgilere bakınız). İç grup ve dış grup manipülasyonu için katılımcılara barış sürecinin desteklenmesine ilişkin çağrı metnini okumadan önce bir yönerge verilmiştir. Yönergede katılımcılardan okuyacakları çağrı metnini, kendisini Türk (Kürt) olarak tanımlayan biri tarafından kendilerine hitaben yazıldığını düşünerek okumaları istenmiştir. Yönergedeki Türk ve Kürt sözcükleri vurgu amacıyla altı çizili olarak verilmiştir. Katılımcılar çağrı metnini okuduktan sonra sırasıyla İnsanlıktan Uzaklaştırma Ölçeği, Barış Sürecini Destekleme Ölçeği ve Demografik Bilgi Formunu doldurmuştur. İnsanlıktan Uzaklaştırma Ölçeğinin yönergesinde, barış sürecinin desteklenmesi çağrısı yapan kişinin ölçekteki özellikleri ne kadar taşıdığının belirtilmesi; Barış Sürecini Destekleme Ölçeğinin yönergesinde ise katılımcılardan ölçek maddelerindeki etkinliklere (bu etkinliklerin barış sürecinin desteklenmesi çağrısı yapan kişi tarafından istendiğini düşünerek) ne kadar katıldıklarını belirtmeleri istenmiştir.

\section{Bulgular}

Katılımcıların barış sürecini destekleme çağrısı yapan bir iç ya da dış grup üyesine birincil ve ikincil duygu atfetme düzeyleri ile onun barış sürecini destekleme yönündeki etkinliklerini destekleme düzeylerini karş1laştırmak amacıyla 2 (katılımcının etnik kökeni: Türk-Kürt) X 2 (barış sürecini destekleme çağrısı yapanın etnik kökeni: Türk-Kürt) faktöriyel desenine uygun çok yönlü varyans analizi (MANOVA) yapılmıştır.

MANOVA sonuçları, katılımcıların etnik kökeni temel etkisi (Wilks' $\lambda=.41, F(3,80)=38.42, p<.001$, $\left.\eta \mathrm{p}^{2}=.59\right)$, barış sürecini destekleme çağrısı yapanın etnik kökeni temel etkisi (Wilks' $\lambda=.74, F(3,80)=9.55$, $\left.p<.05, \eta p^{2}=.26\right)$ ve katılımcıların etnik kökeni X barış sürecini destekleme çağrısı yapanın etnik kökeni ortak etkisinin (Wilks' $\lambda=.69, F(3,80)=11.80, p<.001, \eta p^{2}$ $=.31$ ) anlamlı olduğunu göstermektedir.

Analiz sonuçları, katılımcıların etnik kökeni temel etkisinin ve barış sürecini destekleme çağrısı yapanın etnik kökeni temel etkisinin birincil duygu (sırasıyla, $\left.F(1,82)=1.87, p>.05, \eta p^{2}=.02 ; F<1\right)$ ve ikincil duygu (sirasiyla, $F(1,82)=3.63, p>.05, \eta p^{2}=.04 ; F(1,82)$ $=3.44, p>.05, \eta p^{2}=.04$ ) atfetme düzeyleri üzerinde anlamlı farklılıklar yaratmadığını göstermektedir. Ancak her iki temel etkinin barış sürecini destekleme çağrısı yapan kişinin barış sürecini desteklemeye yönelik olarak önerdiği etkinliklere katılma düzeyi (bu çalışmanın izleyen kısımlarda bu değişken 'barış sürecinin desteklenmesi' olarak ifade edilecektir) üzerinde anlamlı olduğu görülmektedir (sırasıyla, $F(1,82)=116.03, p<.001, \eta p^{2}$ $\left.=.59 ; F(1,82)=25.65, p<.001, \eta p^{2}=.24\right)$. Kürt kat1lımcılar (Ort. $=5.77, S=0.83)$ Türk katılımcılara kıyasla (Ort. $=3.25, S=1.59$ ) barış sürecini daha fazla desteklemektedir. Barış çağrısını yapan Türk kökenli biri (Ort. $=5.13, S=1.45)$ bu çağrıyı yapan Kürt kökenli birine göre (Ort. $=3.84, S=1.88)$ barış sürecine yönelik desteği daha çok artırmaktadır.

$2 \quad$ Bu maddedeki “organizasyon" kelimesi İngilizce "organization” kelimesine karşılık olarak kullanılmıştır. Ancak bu kelime İngilizcede genellikle örgüt ve kuruluș anlamında kullanılırken Türkçede daha çok etkinlik anlamında kullanılmaktadır. Bu yönüyle organizasyon çevirisinin İngilizce aslını tam olarak karşılamadığı söylenebilir. Bu nedenle, sonraki çalışmalarda bu maddedeki organizasyon sözcügü yerine kuruluş sözcüğünün kullanılmasını öneriyoruz. Bu hususa dikkatimizi çeken hakeme teşekkür ederiz. 
Tablo 1. Katılımcının Etnik Kökeni X Barış Sürecini Destekleme Çağrısı Yapanın Etnik Kökeni Ortak Etkisine Ait Ortalama ve Standart Sapma Değerleri

\begin{tabular}{|c|c|c|}
\hline \multirow[t]{3}{*}{ Katılımcı Etnik Kökeni/Bağımlı Değişkenler } & \multicolumn{2}{|c|}{ Barış Sürecini Destekleme Çağrısı Yapanın Etnik Kökeni } \\
\hline & Türk & Kürt \\
\hline & Ort. (S) & Ort. (S) \\
\hline \multicolumn{3}{|l|}{ Türk Katılımcılar } \\
\hline Birincil Duygu & $2.73(0.77)$ & $2.70(0.78)$ \\
\hline İkincil Duygu & $3.73(0.73) \mathrm{a}$ & $2.70(0.78) \mathrm{b}$ \\
\hline Barış Sürecini Destekleme & $4.31(1.56) \mathrm{a}$ & $2.30(0.85) \mathrm{b}$ \\
\hline \multicolumn{3}{|l|}{ Kürt Katılımcılar } \\
\hline Birincil Duygu & $2.57(0.95)$ & $2.36(0.83)$ \\
\hline İkincil Duygu & $3.30(0.90) \mathrm{a}$ & $3.74(0.41) \mathrm{b}$ \\
\hline Barış Sürecini Destekleme & $5.92(0.75)$ & $5.61(0.90)$ \\
\hline
\end{tabular}

Not. Aynı satır üzerinde farklı harflerle işaretlenen ortalamalar arasında anlamlı fark bulunmaktadır. Çalışmanın hipotezleri kapsamında olmadıkları için sütun içi karşılaştırmalar yapılmamıştır.

Çalışmanın hipotezleri açısından en önemli bulgular, kuşkusuz, katılımcıların etnik kökeni (Türk-Kürt) $\mathrm{X}$ barıș sürecini destekleme çağrısı yapan kișinin etnik kökeni (Türk-Kürt) ortak etkisinden elde edilecek bulgulardır. Bu ortak etkinin birincil duyguların atfedilmesi üzerinde anlamlı bir etkiye sahip olmadığı $(F<1)$, ancak ikincil duyguların atfedilmesi $(F(1,82)=21.39, p<.001$, $\left.\eta \mathrm{p}^{2}=.21\right)$ ve barıș sürecinin desteklenmesi $(F(1,82)=$ $\left.13.84, p<.001, \eta p^{2}=.14\right)$ düzeyleri üzerinde anlam11 etkilere sahip olduğu görülmektedir. Ortak etkiye ait gruplar arası karşılaştırmalar Tablo 1'de verilmektedir.

Tablo 1'den de görülebileceği gibi, Türk katılımc1lar birincil duyguları iç gruba (Türk) ve dış gruba (Kürt) benzer düzeyde atfederken $(t<1)$, ikincil duyguları iç gruba oranla diş gruba daha az atfetmektedir, $t(42)=$ 4.51, $p<.001$. Türk katılımcılar aynı zamanda, barış sürecine destek çağrısı bir dış grup üyesi tarafından yapıldığında barış sürecini daha az destekleme eğilimi göstermektedir, $t(42)=5.37, p<.001$. Diğer yandan, Kürt katılımcılar da birincil duyguları iç gruba (Kürt) ve diş gruba (Türk) eşit düzeyde atfederken $(t<1)$, ikincil duyguları iç gruba oranla dış gruba daha az atfetmektedir, $t(40)=2.06, p<.05$. Ancak, Türk katılımcılardan farkl1 olarak Kürt katılımcılar, iç grup üyesinin ve dış grup üyesinin barış sürecini destekleme çağrıları arasında bir ayrım yapmayarak her ikisinin çağrısından sonra barış sürecini benzer düzeyde destekleme eğilimi göstermektedir, $t(40)=1.20, p>.05$.

\section{Tartışma}

Bu çalıșmada, Türk ve Kürt katılımcıların barış sürecini destekleme çağrısı yapan bir iç grup üyesine k1yasla bir dış grup üyesine daha az ikincil duygu (insana özgü duygular) yükleyerek onu insanlıktan uzaklaştıracağ 1 (Leyens ve ark., 2000, 2003) ve bunun sonucunda onun barıș sürecini destekleme konusundaki çabalarını daha az destekleyeceği öne sürülmüştür. Buna karşın, barış sürecinin desteklenmesi çağrısı yapanın iç grup ya da dış grup üyesi olmasının ona atfedilecek birincil duygu (insana özgü olmayan duygular) üzerinde herhangi bir etkisinin olmayacağı düşünülmüştür.

Bulgular, Türk katılımcıların barış sürecini destekleme çağrısını yapan bir iç grup üyesine oranla çağrıyı yapan diş grup üyesine daha az ikincil duygu atfederek onu insanlıktan uzaklaştırdığını göstermektedir. Bununla bağlantılı olarak, Türk katılımcıların, barıș sürecini destekleme çağrısı dış grup üyesinden geldiğinde barış sürecini destekleme konusunda daha isteksiz davrandıkları anlaşılmaktadır. Bununla birlikte, Türk katılımcılar barış sürecine destek çağrısı yapan iç grup ve dış grup üyelerine birincil duygu atfetmede herhangi bir yanlılığa başvurmayıp her ikisine de aynı düzeyde birincil duygu atfetmiştir. Kürt katılımcılar da Türk katılımcılar gibi çağrıyı yapan dış grup üyesine iç grup üyesiyle aynı düzeyde birincil duygu atfederken, dış grup üyesine daha az ikincil duygu atfetmiştir. Hem Türk hem de Kürt kat1- 
lımcıların birincil duyguların atfında dış grup ayrımcılığına başvurmayıp sadece ikincil duygular konusunda diş gruba karşı ayrımcılığa baş vurması insanlıktan uzaklaştırma yazınındaki bulgularla (örn., Leyens ve ark., 2007; Vaes ve ark., 2012) tutarlıdır ve bu çalışmada öne sürülen hipotezi desteklemektedir. Her iki etnik grubun kendi grubuna daha fazla ikincil duygu atfetmesi ilgili yazınla tutarlı olarak (örn., Leyens ve ark., 2001) iç gruba k1yasla dış grubun ikincil duyguları yaşama kapasitesinin daha az olduğuna inanılmasıyla açıklanabilir.

Türk katılımcılar dış grup üyesine daha az ikincil duygu yakıştırarak sergiledikleri ayrımcılığı, dış grup üyesinin barış sürecini desteklemeye yönelik olarak önerdiği etkinliklere daha az katılma niyeti göstererek sürdürmüştür. Dolayısıyla, Türk katılımcılar bağlamında insanlıktan uzaklaştırma eğiliminin barıș sürecine zarar verdiği söylenebilir. Ancak Kürt katılımcılar, Türk kat1lımcılardan farklı olarak ikincil duygu atfında dış gruba karşı sergiledikleri ayrımcılığı barış sürecinin desteklenmesi konusunda sürdürmemiştir. Diğger bir deyişle, Kürt katılımcılar arasında barış sürecine destek düzeyi, barış çağrısı dış grup üyesinden geldiğinde iç grup üyesinden geldiğinde olduğu kadar yüksek olmuştur. Türk katılımcıların iç grubunkilere kıyasla dış grubun barış sürecini destekleme konusundaki çabalarına karşı daha olumsuz bir tavırda olması, bu çalışmada öne sürülen hipotezi desteklemektedir. Bu bulgu, insanlıktan uzaklaştırmanın gruplar arası olumlu tutumlara (örn., DeLuca-McLean ve Castano, 2009), davranışsal niyetlere (örn., Cuddy ve ark., 2007) ve barışa (örn., Tam ve ark., 2007, 2008; Wohl ve ark., 2012) zarar verebildiğine ilişkin yazınla da tutarlıdır. Ancak Kürt katılımcıların dış gruba yönelik ikincil duygu atfında sergiledikleri ayrımcılığ grubun barış çabalarını destekleme konusunda sergilememesi çalışmanın beklentileri ile uyumlu olmadığı gibi bahsi geçen yazınla da tutarlı değildir.

Kürt katılımcıların ikincil duygu atfında gruplar arası ayrımcılığa başvurması ama bunu dış gruba yönelik tutumlarına yansıtmaması nasıl açıklanabilir? Bu çalışmadaki dikkat çekici bulgulardan birisi Kürt katılımcıların barış sürecini destekleme düzeyinin Türk katılımcılarınkinden daha yüksek olmasıdır. Barış sürecine yönelik toplumsal desteğin araştırıldığı kamuoyu araştırmalarında da (Bilgesam, 2013; Habertürk, 2013; T24, 2013) Kürtlerin Türklere oranla barış sürecini daha çok destekledikleri görülmektedir. Bu bulgular birlikte düşünüldüğünde, Kürt katılımcıların barış sürecini daha çok desteklemesi ile sosyopolitik nedenler arasında ilişki kurulabilir. Şöyle ki Kürt sorunu kaynaklı şiddet ve çatışma ortamı daha çok Kürt nüfusun yoğun olarak yaşadığ1 Doğu ve Güneydoğu Anadolu bölgelerinde etkili olmuştur. Ayrıca, bazı araştırmalar (örn., Konda, 2011) bu şiddet ortamından etkilenme algısının Kürtler arasın- da daha yaygın olduğunu göstermektedir. Kürt katılımcıların insanlıktan uzaklaştırmaya başvurmasına rağmen barış sürecini yüksek düzeyde desteklemeye devam etmesi, Kürt sorunu kaynaklı çatışma koşullarının onlara daha fazla zarar verdiğini algılamalarıyla ilişkili olabilir. Kürt katılımcılar daha çok zarar gördüklerine inandıkları için bu çatışma ortamının her şeye rağmen sona ermesini istemiş olabilirler.

Kürt katılımcılardan elde edilen bulgular için, sosyopolitik konularda dezavantajlı grupların avantajlı gruplardan farklılaşan motivasyonlarına dikkat çeken kolektif eylem yazınından da bir açıklama getirilebilir. Kolektif eylem yazını (örn., van Zomeren, Postmes ve Spears, 2008), dezavantajlı grupların kendilerine zarar verdiğine inandıkları toplumsal koşulları değiştirme olasılığı olan kolektif eylemlere daha olumlu yaklaştıklarını ve daha etkin katıldıklarını göstermektedir. Kürt katılımcılar mevcut çatışma ortamında Kürtlerin daha fazla acı çektiğini düşünmüş olabilirler. Barış sürecinin bu dezavantajlı konumlarını iyileştirme potansiyeli taşıdığına inanmıș ve bu nedenle barıș sürecini daha çok desteklemek istemiş olabilirler (örn., Bağcı ve Turnuklu, 2019; Çakal, Hewstone, Güler ve Heath, 2016).

\section{Çalışma 2}

$\mathrm{Bu}$ çalışma, dış grup üyeleri isteklerini ikincil duygular kullanarak dile getirirlerse, örneğin barış sürecinin desteklenmesine ilişkin bir çağrıyı ikincil duyguları kullanarak yaparlarsa nasıl karşılanırlar sorusuna yanıt aramak için tasarlanmıştır. Vaes ve arkadaşlarına göre (2006), diş grup üyeleri kendilerini insana özgü duygularla ifade ettiklerinde, bu duyguları yaşama kapasitelerine inanılmadığı ya da samimi görülmedikleri için antipatik olarak algilanmakta ve bunun sonucunda kendilerine yönelik olumsuz davranışlara başvurulmaktadır (Vaes ve ark., 2003, 2004, 2011). Bu durum, birincil duygular söz konusu olduğunda ise gerçekleşmemektedir.

$\mathrm{Bu}$ bilgiler 1şı̆̆ında, barış sürecinin desteklenmesi çağrısını birincil ya da ikincil duygularla yapan iç ve dış grup üyelerine ikincil duygu atfetme düzeyi (insanlıktan uzaklaştırma düzeyi) ve onların barış sürecinin desteklenmesine yönelik etkinliklerine destek verme düzeyine ilişkin aşağıdaki hipotezler kurulmuştur:

1. Barış sürecini destekleme çağrısı ikincil duygular kullanılarak (bir iç grup ya da dış grup üyesi tarafından) yapıldığında, dış grup üyesine daha az ikincil duygu atfedilecek bunun sonucunda dış grup üyesinin barış sürecini desteklemeye yönelik etkinliklerine karşı daha olumsuz bir tavır alınacaktır.

2. Barış sürecini destekleme çağrısı birincil duygular kullanılarak yapıldığında ise hem iç grup ve dış grup üyesine atfedilecek ikincil duygu düzeyinde hem de on- 
ların barış sürecini desteklemeye yönelik etkinliklerini desteklenme düzeyinde fark olmayacaktır.

3. Barış sürecini destekleme çağrısı ister birincil duygular ister ikincil duygular kullanılarak yapılsın, iç grup ve diş grup üyelerine atfedilecek birincil duygu düzeyinde bir farklılaşma olmayacaktır.

4. Yukarıdaki hipotezlerde dile getirilen beklentiler hem pozitif hem de negatif duygular için geçerli olacaktır.

\section{Yöntem}

\section{Örneklem}

Çalışmanın örneklemi Ankara ve Mardin'deki Üniversitelerde eğitim gören 365 lisans öğrencisinden oluşmaktadır (Yaş aralığı: 18-35 (Ort. $=22.21, S=3.23$ ); 165 Kürt (\%45), 200 Türk (\%55); 219 kadın (\%60), 146 erkek $(\% 40))$.

\section{Veri Toplama Araçları \\ Manipülasyon Düzenlemeleri}

Katılımcılara ilk çalışmada kullanılan barış çağrıs1 metninin aynısı okutulmuştur. Ancak ilk çalışmadan farklı olarak, çağrı metnine, ön çalışmada insani özü yansıtma düzeyleri ve olumluluk düzeyleri açısından denkleştirilmiş pozitif ve negatif ikişer birincil duygu (haz alma, yakın hissetme; korku, üzüntü) ile ikișer ikincil duygu (umut, gurur; hayal kırıklığl, inancını yitirme) içeren 22-29 sözcükten oluşan bir paragraf eklenmiştir. Eklenen paragrafta çağrıyı yapan kişi bu duygu kümelerinden birini kullanarak Kürt sorununa yönelik bu güne kadarki tutumunu ve bundan sonraki beklentilerini ifade etmektedir (bkz. Ek-2). Dolayısıyla, ikinci çalışma 2 (çağrıyı yapanın grubu: Kürt-Türk) X 2 (duygu türü: birincil-ikincil) X 2 (duygu değeri: pozitif-negatif) faktöriyel desenine uygun olarak hazırlanmıştır.

İç grup-dış grup manipülasyonu, ilk çalışmada olduğu gibi, barış çağrısını yapanın etnik kimliği Türk ve Kürt olarak değiştirilerek yapılmıştır. Duygu türü (birincil-ikincil) ve duygu değeri (pozitif-negatif) manipülasyonları ise yukarıdaki dört duygu çifti kullanılarak yapılmıştır. Bu çalışmada katılımcıların koşullara seçkisiz atanmasında izlenen yol ilk çalışmadakiyle aynıdır. Katılımcıların etnik kökeni, ilk çalışmada olduğu gibi demografik bilgi formundaki etnik köken sorusuna verilen yanıtlar üzerinden belirlenmiştir.

Manipülasyon metnine yerleştirilmek amacıyla seçilen söz konusu birincil ve ikincil duyguların insana özgü olma düzeyi açısından birbirinden farklılaşması, olumluluk düzeyi (pozitiflik-negatiflik düzeyi) açısından ise birbirine denk olması sağlanmıştır. İnsanlıktan Uzaklaştırma Ölçeği için kullanılan duyguların denkleştirilmesinde izlenen yöntemin aynısı burada da uygulanmıștır (bkz. çalışma 1 yöntem bölümü). Böylece, pozitif ve negatif ikincil duyguların pozitif ve negatif birincil duygulardan insana özgü olma düzeyi açısından yüksek olması ama olumluluk düzeyi açısından denk olması sağlanmıştır. Bu koşulun sağlanması, elde edilecek gruplar arası bir farkın manipülasyon metninde kullanılan duyguların olumluluk düzeyinden değil, insana özgü olma düzeyinden kaynaklandığının söylenmesini mümkün kılmaktadır.

\section{Bağımlı Değişkenler}

İlk çalışmada olduğu gibi, bu çalışmada da birincil ve ikincil duygu düzeyini ölçmek için İnsanlıktan Uzaklaştırma Ölçeği, barış sürecini destekleme çağrısını yapan kişinin barış sürecini desteklemeye yönelik olarak önerdiği etkinlikleri destekleme düzeyini belirlemek içinse Barış Sürecini Destekleme Ölçeği kullanılmıştır.

\section{Insanlıktan Uzaklaştırma Ölçeği}

İlk çalışmada kullanılan altışar maddeli birincil duygu ( $\alpha$ : .66) ve ikincil duygu ( $\alpha$ : .59) alt testleri bu çalışmada da kullanılmıştır. İlk çalışmada olduğu gibi bu çalışmada da birincil duygu alt testindeki 'sakin olma' duygusu, bu alt testin güvenirlik düzeyini düşürdüğü için ölçekten çıkarılmıştır (bu madde çıkarılmadan önce $\alpha$ : .55). Ancak ikinci çalışmadan farklı olarak, bu çalışmada ikincil duygu alt testinden herhangi bir madde çıkarılmamıştır.

\section{Barış Sürecini Destekleme Ölçeği}

İlk çalışmada kullanılan ölçek herhangi bir değişiklik yapılmadan bu çalışmada da kullanılmıştır ( $\alpha$ : .95).

\section{Demografik Bilgi Formu}

Demografik Bilgi Formunda katılımcılardan etnik köken, yaş, cinsiyet vb. konularda bilgi vermeleri istenmiştir. İlk çalışmada olduğu gibi, katılımcılar deneyin en son aşamasında demografik soruları yanıtlamışlardır. Etnik köken bilgisi, katılımcıların etnik kökeni değişkenini belirlemek için kullanılmıştır. Etnik kökenini Türk veya Kürt olarak belirtmeyen katılımcılar analizlere dâhil edilmemiştir.

\section{İşlem}

Veriler ilk çalışmada olduğu gibi 2014 yılının Mart ve Mayıs ayları arasında, barış süreci devam ederken toplanmıştır. Verilerin toplanması, sınıf ortamında araştırmacılar tarafından gerçekleştirilmiştir.

Bilgilendirilmiş onamın ardından, Türk ve Kürt katılımcılar 2 (barış çağrısını yapanın grubu: Türk-Kürt) X 2 (duygu türü: birincil-ikincil) X 2 (duygu değeri: pozitif-negatif) faktöriyel desenindeki koşullara, birinci çalışmada anlatılana benzer bir yöntemle seçkisiz olarak atanmışlardır. Tük katılımcıların oluşturduğu örneklemde koşul başına 24-29 kişi düşerken, Kürt katılımcıların oluşturduğu örneklemde koşul başına 20-23 kişi düşmektedir. 
Tablo 2. Türk Katılımcılarda Duygu Türü X Barış Sürecini Destekleme Çağrısı Yapanın Etnik Kökeni Ortak Etkisine Ait Ortalama ve Standart Sapma Değerleri

\begin{tabular}{|c|c|c|c|}
\hline \multirow[t]{3}{*}{ Bağımlı Değişkenler } & \multirow[t]{3}{*}{$\begin{array}{l}\text { Barış Sürecini Destekleme Çağrısı Yapanın } \\
\text { Etnik Kökeni }\end{array}$} & \multicolumn{2}{|c|}{$\begin{array}{l}\text { Barış Sürecini Destekleme Çağrısının } \\
\text { Yapıldığı Duygu Türü }\end{array}$} \\
\hline & & Birincil Duygu & İkincil Duygu \\
\hline & & Ort. (S) & Ort. (S) \\
\hline \multicolumn{4}{|l|}{ Birincil Duygu } \\
\hline & İç Grup (Türk) & $2.98(0.71)$ & $2.84(0.85)$ \\
\hline & Dış Grup (Kürt) & $2.70(0.73)$ & $2.57(0.77)$ \\
\hline \multicolumn{4}{|l|}{ İkincil Duygu } \\
\hline & İç Grup (Türk) & $3.72(0.85) \mathrm{a}$ & $3.94(0.73) \mathrm{a}$ \\
\hline & Dış Grup (Kürt) & $3.22(0.75) \mathrm{b}$ & $3.01(0.81) \mathrm{b}$ \\
\hline \multicolumn{4}{|c|}{ Barış Sürecini Destekleme } \\
\hline & İç Grup (Türk) & $3.78(1.43)$ & $4.48(1.66)$ \\
\hline & Dış Grup (Kürt) & $3.54(1.43)$ & $3.48(1.87)$ \\
\hline
\end{tabular}

Not. Aynı sütunda farklı harflerle simgelenen ortalamalar arasında anlamlı fark bulunmaktadır. Çalışmanın hipotezleriyle ilişkili olmadıkları için satır içi karşılaştırma yapılmamıştır.

Katılımcılar metni okuduktan sonra sırasıyla İnsanlıktan Uzaklaştırma Ölçeği, Barış Sürecini Destekleme Ölçeği ve Demografik Bilgi Formunu doldurmuştur. İlk çalışmada kullanılan tüm yönergeler değiştirilmeden bu çalışmada da kullanılmıştır.

\section{Bulgular}

Türk ve Kürt katılımcıların bağımlı değişkenlerden (birincil duygu atfi, ikincil duygu atfı, barış sürecini destekleme) aldıkları puanlar, 2 (barış çağrısının yapanın grubu: Türk-Kürt) X 2 (duygu türü: birincil-ikincil) X 2 (duygu değeri: pozitif-negatif) faktöriyel desenine uygun çok yönlü varyans analizi (MANOVA) yapılarak karşılaştırılmıştır. Bu çalışmanın hipotezlerinin odağında iç grup ve dış grup farklılaşması olduğu için (ve daha yalın bir bulgu raporu için) iç grup-dış grup karşılaştırması içermeyen etkilere ait karşılaştırmalar rapor edilmemiştir.

\section{Türk Katılımcılara Ait Bulgular}

MANOVA sonuçları, barış sürecini destekleme çağrısı yapanın grup üyeliği temel etkisi (Wilks' $\lambda=.84$, $\left.F(3,190)=11.78, p<.001, \eta p^{2}=.16\right)$, duygu değeri temel etkisi (Wilks' $\lambda=.87, F(3,190)=9.81, p<.001, \eta p^{2}$ $=.13$ ) ve duygu türü $X$ barış çağrısı yapanın grup üyeliği ortak etkisinin (Wilks' $\lambda=.95, F(3,190)=2.93, p<.05$, $\eta \mathrm{p}^{2}=.05$ ) anlamlı olduğunu göstermektedir. Diğer temel ve ortak etkilerin ise anlamlı olmadığı anlaşılmaktadır (tüm $F$ değerleri $\leq 1.29$, tüm $p$ değerleri $>.05$ ).
Barış sürecini destekleme çağrısı yapanın grup üyeliği temel etkisine ilişkin analiz sonuçları, iç gruba kıyasla dış gruba hem daha az birincil duygu (sırasıyla, Ort. = 2.92; $S=0.78 ;$ Ort. $=2.64, S=0.75$ ) hem de daha az ikincil duygu (sirasiyla, Ort. $=3.78, \mathrm{~S}=0.80 ;$ Ort.$=3.16$, $S=0.78$ ) atfedildiğini göstermektedir (sirasılla, $F(1,192)$ $=6.73, p<.01 ; \eta p^{2}=.03 ; F(1,192)=34.10, p<.001, \eta p^{2}$ $=.15)$. Ek olarak, katılımcıların iç grup üyesinin çağrısına kıyasla (Ort. $=4.12, S=1.58)$ diş grup üyesinin çağrısı sonrasında (Ort. $=3.51, S=1.65$ ) barış sürecini destekleme çağrısı yapan kişinin barış sürecini desteklemeye yönelik olarak önerdiği etkinlikleri (ilk çalışmada olduğu gibi bu çalışmanın izleyen kısımlarda da bu değişken 'barış sürecinin desteklenmesi' olarak ifade edilecektir) daha az destekleme eğilimi gösterdikleri görülmektedir, $F(1,192)=7.34, p<.01, \eta p^{2}=.04$.

Analiz sonuçları, çalışmanın hipotezleri açısından daha önemli olan duygu türü X barış çağrısı yapanın etnik kökeni ortak etkisinin ikincil duygu atfetme düzeyi üzerinde etkili olduğunu $\left(F(1,192)=5.39, p<.05, \eta p^{2}\right.$ $=.03)$, ancak birincil duygu atfetme düzeyi üzerinde $(F<1)$ ve barış sürecini destekleme düzeyi üzerinde $\left(F(1,192)=2.68, p>.05, \eta p^{2}=.01\right)$ etkili olamadığını göstermektedir. Bu etkileşimlere ait gruplar arası karş1laştırmalar Tablo 2'de verilmektedir.

Tablo 2'den de görülebileceği gibi, katılımcıların barış sürecini destekleme çağrısını ikincil duygular kullanarak yapan bir diş grup üyesine bir iç grup üyesinden daha az ikincil duygu atfettiği görülmektedir, $t(101)=$ 
Tablo 3. Kürt Katılımcılarda Duygu Türü X Barış Sürecini Destekleme Çağrısı Yapanın Etnik Kökeni Ortak Etkisine Ait Ortalama ve Standart Sapma Değerleri

\begin{tabular}{|c|c|c|c|}
\hline \multirow[t]{3}{*}{ Bağımlı Değişkenler } & \multirow[t]{3}{*}{$\begin{array}{l}\text { Barış Sürecini Destekleme Çağrısı Yapanın } \\
\text { Etnik Kökeni }\end{array}$} & \multicolumn{2}{|c|}{$\begin{array}{l}\text { Barış Sürecini Destekleme Çağrısının } \\
\text { Yapıldığı Duygu Türü }\end{array}$} \\
\hline & & Birincil Duygu & İkincil Duygu \\
\hline & & Ort. (SS) & Ort. (SS) \\
\hline \multicolumn{4}{|l|}{ Birincil Duygu } \\
\hline & İç Grup (Kürt) & $2.96(1.18)$ & $3.34(1.30) \mathrm{a}$ \\
\hline & Dış Grup (Türk) & $2.86(0.71)$ & $2.34(0.81) \mathrm{b}$ \\
\hline \multicolumn{4}{|l|}{ İkincil Duygu } \\
\hline & İç Grup (Kürt) & $3.50(0.84)$ & $4.41(0.84) \mathrm{c}$ \\
\hline & Dış Grup (Türk) & $3.79(0.80)$ & $3.06(0.64) \mathrm{d}$ \\
\hline \multicolumn{4}{|c|}{ Barıș Sürecini Destekleme } \\
\hline & İç Grup (Kürt) & $5.08(1.72) \mathrm{a}$ & $6.09(1.10) \mathrm{e}$ \\
\hline & Dış Grup (Türk) & $5.83(1.55) b$ & $4.48(1.73) \mathrm{f}$ \\
\hline
\end{tabular}

Not. Her bağımlı değişken için ayrı olmak üzere aynı sütunda farklı harflerle simgelenen ortalamalar arasında anlamlı fark bulunmaktadır. Çalışmanın hipotezleriyle ilişkili olmadıkları için satır içi karşılaştırma yapılmamıştır.

$3.18, p<.01$. Benzer şekilde, katılımcıların barış sürecini destekleme çağrısını birincil duygular kullanarak yapan bir dış grup üyesine de bir iç grup üyesinden daha az ikincil duygu atfettiği görülmektedir, $t(95)=4.77, p<$ .001. Ayrıca, barış sürecini destekleme düzeyinin de bu etkileşimden beklenen yönde etkilendiği görülmektedir. İkincil duygular kullanılarak yapılan barış sürecini destekleme çağrısını dış grup üyesinden alanlar bu çağrıyı iç grup üyesinden alanlara göre barış sürecini daha az desteklemiştir. Benzer şekilde, birincil duygular kullanılarak yapılan barış sürecini destekleme çağrısını dış grup üyesinden alanlar da bu çağrıyı iç grup üyesinden alanlara göre barış sürecini daha az desteklemiştir. Ancak üst paragrafta rapor edilen $F$ değerinden de anlaşılacağı gibi, barış sürecinin desteklenmesine ilişkin iki grup arasındaki bu farklar anlamlılık düzeyine ulaşmamıştır. Bununla birlikte, birincil duygu koşuluna göre ikincil duygu koşulunda barış sürecini destekleme konusundaki iç grup ve dış grup arasındaki farkın daha yüksek olduğu dikkat çekmektedir.

\section{Kürt Katılımcılara Ait Bulgular}

Kürt katılımcılar için de 2 (duygu türü: birincil duygu-ikincil duygu) X 2 (barış sürecini destekleme çağrısını yapanın grup üyeliği: iç grup-dış grup) X 2 (duygu değeri: pozitif-negatif) faktöriyel desenine uygun çok yönlü varyans analizi (MANOVA) yapılmıştır. Sonuçlar, barış çağrısı yapanın grup üyeliği temel etkisi (Wilks' $\lambda$ $\left.=.87, F(3,155)=7.80, p<.001, \eta p^{2}=.13\right)$, duygu de- ğeri temel etkisi (Wilks' $\lambda=.71, F(3,155)=20.85, p<$. $\left.001, \eta p^{2}=.29\right)$, duygu türü $X$ barış çağrısı yapanın grup üyeliği ortak etkisi (Wilks' $\lambda=.70, F(3,155)=22.51, p$ $\left.<.001, \eta \mathrm{p}^{2}=.30\right)$ ve duygu türü $\mathrm{X}$ duygu değeri ortak etkisinin (Wilks' $\lambda=.94, F(3,155)=3.52, p<.05, \eta p^{2}$ $=.06$ ) anlamlı olduğunu göstermektedir. Diğer temel ve ortak etkilerin ise anlamlı olmadığ 1 anlaşılmaktadır (tüm $F$ değerleri $\leq 1.23$, tüm $p$ değerleri $>.05$ ).

Barıș çağrısı yapanın grup üyeliği temel etkisine ilișkin analiz sonuçları, iç gruba kıyasla dıș gruba hem daha az birincil duygu (sirasiyla, Ort. $=3.16, S=1.25$; Ort. $=2.60, S=0.80$ ) hem daha az ikincil duygu (sirasiyla, Ort. $=3.97, S=0.95 ;$ Ort. $=3.42, S=0.81$ ) atfedildiğini göstermektedir (sırasıyla, $F(1,157)=13.20, p<$ $\left..001, \eta p^{2}=.08 ; F(1,157)=22.05, p<.001, \eta p^{2}=.12\right)$. Ek olarak, katılımcıların barış sürecini desteklemesi barış sürecini destekleme çağrısı iç grup (Ort. $=5.60, \mathrm{~S}$ $=1.52$ ) yerine diş grup tarafından yapıldığında (Ort. $=$ $5.14, S=1.77)$ daha düşük olmaktadır, $F(1,157)=3.37$, $p=.068, \eta p^{2}=.02$.

Analizi sonuçları, çalışmanın hipotezleri açısından daha önemli olan duygu türü $X$ barış çağrısı yapanın etnik kökeni ortak etkisinin birincil duygu atfetme $\left(F(1,157)=8.44, p<.01, \eta p^{2}=.05\right)$, ikincil duygu atfetme $\left(F(1,157)=51.68, p<.001, \eta p^{2}=.25\right)$ ve barış sürecini destekleme $\left(F(1,157)=25.70, p<.001, \eta p^{2}=.14\right)$ düzeyleri üzerinde de etkili olduğunu göstermektedir. $\mathrm{Bu}$ etkileşimlere ait gruplar arası karşılaştırmalar Tablo 3 'te verilmektedir. 
Tablo 3'ten de görülebileceği gibi, barış sürecini destekleme çağrısı ikincil duygular kullanılarak yapıld1ğında iç grup üyesine oranla dış grup üyesine hem daha az birincil duygu $(t(82)=4.23, p<.001)$ hem de daha az ikincil duygu $(t(82)=8.27, p<.001)$ atfedilmekte; barış sürecini destekleme düzeyi ise beklentilerle uyumlu olarak, dış grup koşulunda iç grup koşulundan daha düşük çıkmaktadır, $t(82)=5.11, p<.001$. Barış sürecini destekleme çağrısını birincil duyguları kullanarak yapan iç grup ve diş grup üyelerine atfedilen birincil ve ikincil duygu düzeyleri birbirinden farklılaşmamaktadır (sırasıyla, $t<1$; $t(79)=1.59, p>.05)$; ancak, beklentilerin aksine, barış sürecini destekleme düzeyi dış grup koşulunda iç grup koşulundan daha yüksek çıkmaktadır, $t(79)=-2.05, p<.05$.

\section{Tartıșma}

Bu çalışmada, barış sürecinin desteklenmesi çağr1sını birincil ya da ikincil duygularla yapan iç ve dış grup üyelerine ikincil duygu atfetme düzeyinin (insanlıktan uzaklaştırma düzeyinin) ve onların barıș sürecinin desteklenmesine yönelik etkinliklerine destek verme düzeyinin nasıl değiştiği araştırılmaktadır. Barış sürecini destekleme çağrısını yapanın grup üyeliği (iç grup-dış grup) temel etkisine ilişkin bulgular hem Türk katılımcıların hem de Kürt katılımcıların iç grup üyesine kıyasla dış grup üyesine daha az ikincil duygu atfettiğini göstermektedir. Ayrıca her iki etnik gruba mensup katılımcılar barış sürecini destekleme çağrısı dış grup üyesinden geldiğinde barış sürecini daha az destekleme eğilimi göstermiştir. Bu bulgular, her iki etnik gruba mensup katılımcıların barış çağrısı yapan dış grup üyesini insanlıktan uzaklaştırdığına (Leyens ve ark., 2003, 2007) ve bunun etkisiyle diş grup üyesinin barış sürecini desteklemeye yönelik isteklerine daha olumsuz yaklaştığına (Cuddy ve ark., 2007; Tam ve ark., 2007, 2008; Wohl ve ark., 2012) işaret etmektedir.

$\mathrm{Bu}$ çalışmanın hipotezleriyle doğrudan bağlantılı olan duygu türü (birincil-ikincil) X barış sürecini destekleme çağrısı yapanın grup üyeliği ortak etkisine ilişkin bulgular, Türk katılımcıların barış sürecini destekleme çağrısını ikincil duyguları kullanarak yapan bir dış grup üyesine (bir iç grup üyesine kıyasla) daha az ikincil duygu atfettiğini göstermektedir. Kürt katılımcılar da Türk katılımcılar gibi barış sürecini destekleme çağrısını ikincil duyguları kullanarak yapan bir dış grup üyesine (bir iç grup üyesine kıyasla) daha az ikincil duygu atfetmiş görünmektedir. Aynı zamanda, hem Türk hem de Kürt katılımcıların ikincil duyguları kullanarak barış sürecine destek çağrısı yapan dış grup üyesinin çağrısı sonrasında (iç grup üyesinin yaptığı çağrı sonrasına kıyasla) barış sürecini daha az destekledikleri görülmektedir. Kürt katılımcıların ilk çalışmadan farklı olarak, dış grup üyesini insanlıktan uzaklaştırmanın yanında barış sürecini de daha az desteklemelerinin olası bir nedeni, Vaes ve arkadaşlarının (2006) öne sürdüğü gibi, barış çağrısını ikincil duyguları kullanarak yapmanın dış grup üyesini antipatikleştirmesi olabilir. Kürt katılımcıların dış grup üyesi birincil duyguları kullanarak barış sürecini destekleme çağrısı yaptığında (ikincil duygularla yaptığı zamana k1yasla) barış sürecini daha fazla desteklemiş olmaları bu çıkarımı desteklemektedir.

Bu bulgular, Vaes ve arkadaşlarının (2006) bulgularıyla tutarlı olarak, her iki etnik gruba mensup katılımcıların, barış sürecini desteklemeye yönelik isteklerini insana özgü duygular yardımıyla dile getiren dış grup üyelerini samimi görmedikleri ve/veya bu duyguları yaşama kapasitesinden yoksun buldukları için onlara daha az ikincil duygu yükleyerek onları insanlıktan uzaklaştırdıklarına işaret etmektedir. Aynı zamanda, isteklerini ikincil duygular yardımıyla dile getiren dış grup üyelerinin, insanlıktan uzaklaştırılmanın yanında nahoş ya da ayrımcı tutum ve davranışlara da maruz kaldıklarını (Vaes ve ark., 2003, 2004, 2011) ve bu ayrımc1 eğilimin gruplar aras1 barışa ilişkin tutumlar söz konusu olduğunda da geçerli olabildiğini (Wohl ve ark., 2012) göstermektedir. Bu çalışmanın hipotezleriyle de uyumlu olan bu bulgular insanlıktan uzaklaştırma eğiliminin hem Türk hem de Kürt katılımcıların barış sürecine ilişkin tutumlarını olumsuz yönde etkileyebildiğine ișaret etmektedir.

Diğer yandan, iç grup-diş grup temel etkisi ve duygu türü X iç grup-dış grup ortak etkisine ait bazı bulgular, katılımcıların insanlıktan uzaklaştırmanın yanı sıra iç grup yanlılığına da (Brewer, 1999; Tajfel ve Turner, 1979) başvurmuş olabileceklerini akla getirmektedir. Şöyle ki, ilk olarak, iç grup-dış grup temel etkisine ilişkin bulgular, her iki etnik gruba mensup katılımcıların dış gruba kıyasla iç gruba sadece ikincil duyguları değil birincil duyguları da daha çok atfettiğini göstermektedir. İkinci olarak, Türk katılımcılar dış grup üyesi barış sürecini destekleme çağrısını birincil duygularla dile getirdiğinde de ona daha az ikincil duygu atfetmiştir. Üçüncü olarak, Kürt katılımcılar barış sürecini destekleme çağrısını ikincil duygularla yapan dış grup üyesine sadece daha az ikincil duygu yüklemekle kalmayarak birincil duyguları da daha az yüklemiştir. Bu bulgulardan yola çıkarak diş gruba daha az ikincil duygu atfedilmesinin insanlıktan uzaklaştırmadan değil de iç grup yanlılığından kaynaklanmış olabileceği ileri sürülebilir. Ancak, ikincil duygu konusundaki gruplar arası farklara ait etki büyüklüklerinin birincil duygu konusundaki farklara ait etki büyüklüklerinden çok daha büyük olduğu dikkate alındığında, ikincil duygu atfetme konusundaki yanlılığın iç grup yanlılığından çok daha güçlü olduğu sonucuna varılabilir. $\mathrm{Bu}$ ise iç grup ve dış grup arasında ikincil duygu konusundaki farklılaşmaların iç grup yanlılığından da etkilenmekle birlikte esas olarak insan- 
lıktan uzaklaştırma eğiliminden kaynaklandığı şeklinde yorumlanabilir.

Son olarak, ilk çalışmada olduğu gibi, tüm deneysel koşullarda Kürt katılımcıların barış sürecini destekleme düzeyinin Tük katılımcılarınınkinden daha yüksek olduğu görülmektedir. Bu bulgu, ilk çalışmanın tartışma bölümünde de açıklandığı gibi, Kürt katılımcıların dezavantajlı koşullarından duydukları memnuniyetsizlik dolayısıyla sosyal değişimi hedefleyen kolektif eylemlere katılmaya daha istekli olmalarıyla açıklanabilir (örn., Çakal ve ark., 2016; van Zomeren ve ark., 2008). Daha açık bir ifadeyle, Kürt katılımcılar çatışma ortamının ağır yüklerini omuzlarından kaldıracağına inandıklarından dolayı barış sürecini daha fazla desteklemiş olabilirler.

\section{Genel Tartıșma}

$\mathrm{Bu}$ araştırma kapsamında yürütülen iki çalışmadan elde edilen bulgular, Kürt sorununa yönelik 2013 yılında başlatılan barış sürecinin desteklenmesi konusunda Türkiye toplumunda görülen bölünmüşlüğün insanlıktan uzaklaştırma eğilimiyle ilişkili olabileceğini ortaya koymaktadır. İnsanlıktan uzaklaştırma yazınıyla tutarlı olarak, her iki çalışmada hem Türk hem de Kürt katılımcılar barış sürecinin desteklenmesi çağrısı yapan dış grup üyesine ikincil duyguları daha az yükleyerek onu insanlıktan uzaklaştırma eğilimi göstermiştir. İlk çalışmada, bu eğilimin dış grubun barış sürecini desteklemeye yönelik etkinliklerine destek niyetini zayıflatması Türk katılımcılar arasında gözlenirken Kürt katılımcılar arasında gözlenmemiştir. İkinci çalışmada ise Kürt katılımcılar da Türk katılımcılar gibi, barış sürecini destekleme çağrısını ikincil duygular kullanarak yapan dış grup üyesini hem insanlıktan uzaklaştırmış hem de onun barış sürecini desteklemeye yönelik etkinliklerine katılmaya daha soğuk bakmıştır. İkinci çalışmada Kürt katılımcılar arasında gözlenen bu farklılığın bir nedeni, dış grup üyesinin barış çağrısını ikincil duygular kullanarak yapması sonucunda katılımcıların gözünde itici hale gelmiş olmas1 olabilir (Vaes ve ark., 2006).

Diğer yandan, her iki çalışmada da Kürt katılımcıların barış sürecini destekleme niyetinin Türk katılımc1larınkinden daha yüksek olması dikkat çekicidir. Bu bulgu dezavantajlı grupların, koşullarını iyileştirecek kolektif eylemleri desteklemeye daha istekli olduklarına ilişkin kolektif eylem yazınındaki bulgularla uyumludur. Şöyle ki, Kürt katılımcılar Kürt sorunu kaynaklı şiddetin kendilerine daha çok zarar verdiğine ve barış sürecinin bu dezavantajlı durumu ortadan kaldırabileceğine daha çok inanmış oldukları için barış sürecini daha çok desteklemiş olabilirler.

Sonuç olarak, her iki çalışmadan elde edilen bulgular her iki etnik gruba mensup katılımcıların öteki grubu kendi grubuna göre insani hiyerarşide daha düşük bir konumda görme eğiliminde olduğunu göstermektedir. Bu eğilimin sonucunda, her iki grup da diğer grup tarafindan yapılan barış sürecini destekleme çağrısı sonrasında barış sürecini desteklemeye daha mesafeli olma eğilimi göstermektedir. Kısaca, Kürt sorununa yönelik barış süreci konusundaki toplumsal görüş ayrılıklarının kısmen de olsa tarafların karşılıklı olarak birbirine eşit insanlık atfetmekten kaçınmasıly ilişkili olduğu öne sürülebilir.

$\mathrm{Bu}$ çalışmanın yazına üç açıdan katkı yaptığı söylenebilir. İlk olarak, çalışma insanlıktan uzaklaştırmanın gruplar arası barış süreçlerini etkileyebileceğine işaret etmektedir. Yazında insanlıktan uzaklaştırma ile gruplar aras1 affetme ve empati gibi kavramlar arasında bağlantı kuran çalışmaların varlığına karşın, gruplar arası barış süreçlerine yönelik tutumlar ile insanlıktan uzaklaştırma arasındaki ilişkiyi doğrudan test eden ilk çalışma bildiğimiz kadarıyla bu çalışmadır. İkinci olarak, çalışma barış süreci ile insanlıktan uzaklaştırma eğilimi arasındaki ilişkiyi gerçekçi bir bağlamda incelemektedir. Araştırmanın verileri barış süreci devam ederken toplanmıştır. Dolayısıyla, elde edilen bulgular gerçekçi bir bağlamda gruplar arası barışa ilişkin davranışsal niyetler ile insanlıktan uzaklaştırma arasındaki ilişkiyi betimlemektedir. Üçüncü olarak, çalışma Türkiye'deki Kürt sorununun çözümünü zorlaştıran psikolojik engellerden birinin tarafların birbirini insanlıktan uzaklaştırması olabileceğini ortaya koymaktadır.

$\mathrm{Bu}$ çalışmanın bazı kısıtlılıkları da bulunmaktadır. İlk olarak, barış süreci bütün toplumsal katmanların tutumundan etkilenen bir olgu olmasına karşın, araştırmanın verileri lisans öğrencilerinden toplanmıştır. Dolayısıyla, bu çalışmanın bulguları genellenirken dikkatli olunmalıdır. İkinci olarak, araştırmada barış sürecini desteklemeye ilişkin tutumlar açık ölçüm alınarak ölçülmüştür. Barışı destekleme gibi olgulara açıktan karşı çıkılması son derece zor olduğu için katılımcıların yanıtlarına sosyal istenirlik bulaşmış olabilir. Dolayısıyla barış sürecini destekleme puanlarının yüksekliğinin kısmen de olsa sosyal istenirlikle ilişkili olabileceği akılda tutulmalıdır. Üçüncü olarak, her iki çalışmada da birincil ve ikincil duygu alt testlerine ait iç tutarlılık düzeyleri geleneksel kabul düzeyinin altında kalmıştır. Bununla birlikte, hem mevcut güvenirlik düzeylerinin az maddeli ölçekler için kabul edilebilir sınırlarda olmasının (örn., Nunnally ve Bernstein, 1994) hem de bulgu örüntüsünün bu testlerin ayırt edici geçerliliğini destekliyor olmasının (örn., birincil ve ikincil duyguların iç grup ve dış gruba atfedilmesindeki farklılıklar) bulguların güvenirliğine ilişkin endişeleri azaltmaktadır. Yine de bu husus sonraki araştırmalarda dikkate alınmalıdır. Bu problemden kaçınmanın bir yolu olarak, insanlıktan uzaklaştırma ölçümü için önceki birçok araştırmada başvurulan bir yöntem olan katılımcıların kendilerine verilen duygu listesinden hedef gruplar için belirli sayıda duygu seçmesini sağlamak daha elverişli bir yol olabilir. 


\section{Öneriler}

$\mathrm{Bu}$ araştırmada da gösterildiği gibi, insanlıktan uzaklaştırma ve benzeri eğilimler (insanlıktan çıkarma, gayrimeşrulaştırma, ahlaki dışlama vb.) gruplar arası ahenge zarar vermektedir (Haslam ve Loughnan, 2014). Önceki araştırmalar, bu eğilimlerin ortaya çıkması ve devam etmesindeki rolleri nedeniyle, gruplar arası ahengi hedefleyen politika ve uygulamalarda gruplar arası çatışma ve tehdit algısını dikkate almanın önemine işaret etmektedir (Bar-Tal, 2000; Leyens ve ark., 2007; Vaes ve ark., 2012). Arşiv verileri bir grubun diğerini düşmanlaştırırken ve onun insanlığını inkâr ederken kullandığı en önemli kanalların medya, ders kitapları ve sanat-edebiyat gibi kültürel araçlar olduğunu göstermektedir (Bezirgan Arar ve Bilgin, 2009; Oren ve Bar-Tal, 2007; Volpato, Durante, Gabbiadini, Andrighetto ve Mari, 2010). Araştırmacılar bu nedenle, bir yandan dış grubun şeytanlaşt1rılmasında medyada ve diğer kanallarda yer alan betimlemelerin kolaylaştırıcı rolüne dikkat çekerken (Esses, Veenvliet, Hodson, ve Mihic, 2008; Leyens ve ark., 2007), diğer yandan dış grupla iç grubun farklılıkları yerine ortak amaç ve çıkarlarının, benzerliklerinin ve dış grubun iç grupla eşit düzeyde insan olduğunun vurgulanması gerektiğini önermektedirler (Bar-Tal, 2000; Kelman, 2008; Tam ve ark., 2008; Wohl ve Branscombe, 2005).

Bu önerilerin Türkiye'de Kürt sorunu bağlamında da geçerli oldukları ve politikacılar tarafından dikkate alınmalarının, tarafların birbirini daha insan olarak görmelerine katkı sağlayacağı söylenebilir. Ayrıca, medya, ders kitapları ve diğer kültürel araçlarda kullanılan dil ve betimlemelerin Türklerin ve Kürtlerin eșitliğini ve uyumunu öne çıkarması, insan hakları ve evrensel medya etiği sınırları içinde, teşvik edilmelidir. Bu son öneri şöyle de genişletilebilir: Bu araştırmanın (özellikle ikinci çalışmanın) bulgularıyla uyumlu olarak, özellikle iç grubun temsilcileri (örn., sanatçılar, politikacılar, gazeteciler, yazarlar) aracılığıyla, karşı tarafın ikincil duygu yaşama kapasitesine atıf ve vurgu yapılması karşı tarafın insanlaştırılmasına ve bunun yardımıyla karşı tarafın görüşlerinin (örn., barışa ilişkin görüşleri) daha samimi ve inandırıcı olarak algılanmasına yardım edebilir (Pereira ve ark., 2009; Vaes ve ark., 2006).

Son olarak, insanlıktan uzaklaştırma çerçevesinin Türk-Kürt ilişkilerinin anlaşılmasında umut vadeden bir potansiyeli olduğuna inanıyoruz. Gelecek araştırmalarda, Türk-Kürt ilişkileri bağlamında, bu eğilimin düzenleyici ve aracı etkilerini ortaya çıkarmaya dönük çalışmalar yapılabilir. Örneğin, gruplar arası çatışma, iç grupla özdeşleşme, sosyal temas gibi düzenleyici değişkenlerle gruplar arası güven ve empati gibi aracı değişkenler bu kapsamda incelenebilir. Konunun belirgin ve baskın bir siyasal boyutunun olması, sosyal baskınlık yönelimi, yetkecilik ve sistemi meşrulaştırma gibi değişkenler aç1sindan da incelenmesini cazip hale getirmektedir.

\section{Kaynaklar}

Aljazeera (10 Ocak 2013). Turkey continues peace talks with the PKK. http://www.aljazeera.com/indepth/ features/2013/01/2013110153318352861.html. Alındiğ 1 tarih: 27.02.2014.

Andrighetto, L., Mari, S., Volpato, C. ve Behluli, B. (2012). Reducing competitive victimhood in Kosovo: The role of extended contact and common ingroup identity. Political Psychology, 33(4), 513529. doi:10.1111/j.1467-9221.2012.00887.x.

Bağci, S. C. ve Turnuklu, A. (2019). Intended, unintended, and unknown consequences of contact: The role of positive-negative contact on outgroup attitudes, collective action tendencies, and psychological well-being. Social Psychology, 50(1), 7-23.

Bar-Siman-Tov, Y. (Ed.). (2004). From conflict resolution to reconciliation. New York: Oxford University Press.

Bar-Tal, D. (2000). From intractable conflict through conflict resolution to reconciliation: Psychological analysis. Political Psychology, 21(2), 351-365. doi: $10.2307 / 3791795$.

Bar-Tal, D. (1998). Societal beliefs in times of intractable conflict: The Israeli case. International Journal of Conflict Management, 9(1), 22-50. doi: 10.1108/ eb022803

Bar-Tal, D. ve Bennink, G.H. (2004). The nature of reconciliation as an outcome and as a process. Yaacov Bar-Siman-Tov (Ed.), From Conflict Resolution to Reconciliation içinde (s. 11-38). Oxford: Oxford University Press.

Bezirgan Acar, Y. ve Bilgin, N. (2009). Gazete haber başlıklarında öteki'nin inşası. Kültür ve İletişim, 12(2), 133-157.

Bilgesam (Haziran, 2013). Çözüm sürecine toplumsal bakış. Bilgesam Yayınları, Rapor No:57, Haziran 2013: http://www.bilgesam.org/Images/Dokumanlar/9-2-2014012036cozumsureci.pdf.

Brewer, M. B. (1999). The psychology of prejudice: Ingroup love and outgroup hate? Journal of Social Issues, 55(3), 429-444.

Cehajic, S., Brown, R. ve Gonzalez, R. (2009). What do I care? Perceived ingroup responsibility and dehumanisation as predictors of empathy felt for the victim group. Group Processes \& Intergroup Relations, 12, 715-729.

Cuddy, A. J. C., Rock, M. S. ve Norton, M. I. (2007). Aid in the aftermath of hurricane Katrina: Inferences of secondary emotions and intergroup helping. Group processes \& Intergroup Relations, 10, 107-118.

Çakal, H., Hewstone, M., Güler, M. ve Heath, A. (2016). 
Predicting support for collective action in the conflict between Turks and Kurds: Perceived threats as a mediator of intergroup contact and social identity. Group Processes \& Intergroup Relations, 19(6), 732-752.

DeLuca-McLean, D. ve Castano, E. (2009). Infra-Humanization of ethnic minorities: The moderating role of ideology. Basic \& Applied Social Psychology, 31(2), 102-108. doi:10.1080/01973530902880258.

Demoulin, S., Leyens, J.P., Paladino, M. P., Rodriguez, R. T., Rodriguez, A. P. ve Dovidio, J. F. (2004). Dimensions of "uniquely" and "non-uniquely" emotions. Cognition and Emotion, 18, 71-96.

Demoulin, S., Leyens, J. Ph., Rodriguez, R. T., Rodriguez, A. P., Paladino, M. P. ve Fiske, S. T. (2005). Motivation to support a desired conclusion versus motivation to avoid an undesirable conclusion: The case of infra-humanization. International Journal of Psychology, 40, 416-428.

Demoulin, S., Cortes, B. P., Viki, T. G., Rodriguez, A. P., Rodriguez, R. T., Paladino, M. P. ve Leyens, J. P. (2009). The role of ingroup identification in infra-humanization. International Journal of Psycho$\log y, 44(1), 4-11$.

Ekman, P. (1992). An argument for basic emotions. Cognition and Emotion, 6, 169-200.

Ensaroğlu, Y. ve Kurban D. (2011). Kürtler ne kadar haklı? Türkiye'nin batısı Kürt sorununa nasıl baklyor. İstanbul: Tesev. http://tesev.org.tr/wp-content/ uploads/2015/11/Kurtler_Ne_Kadar_Hakli_Turkiyenin_Batisi_Kurt_Sorununa_Bakiyor.pdf.

Esses, V. M., Veenvliet, S., Hodson, G. ve Mihic, L. (2008). Justice, morality, and the dehumanization of refugees. Social Justice Research, 21(1), 4-25.

Gaunt, R. (2009). Superordinate categorization as a moderator of mutual infrahumanization. Group Processes \& Intergroup Relations, 12(6), 731746.

Göregenli, M. (2010). Psikolojinin Kürt sorunuyla imtihan1. Eleştirel Psikoloji Bülteni, 3(4), 3-11.

Habertürk (29 Eylül 2013). Bugün seçim olsa. http:// www.haberturk.com/gundem/haber/881600-bugun-secim-olsa. Alındı̆̆ tarih: 01.05.2014.

Haslam, N. (2006). Dehumanization: An integrative review. Personality and Social Psychology Review, 10(3), 252-264.

Haslam, N. ve Loughnan, S. (2014). Dehumanization and infrahumanization. Annual Review of Psychology, 65, 399-423.

Izard, C. E. (1972). Patterns of emotions: A new analysis of anxiety and depression. New York: Academic Press.

Kelman, H.C. (2008). Reconciliation from a social-psy- chological perspcetive. A. Nadler, T. Malloy ve J. D. Fisher (Ed.), Social Psychology of Intergroup Reconciliation içinde (s. 15-32). Oxford: Oxford University Press.

Kentel, F., Ahiska, M. ve Genç F. (2009). Milletin bölünmez bütünlüğü: Demokratikleşme sürecinde parçalayan milliyetcilik(ler). İstanbul: Tesev. http:// www.tesev.org.tr/assets/publications/file/Milletin\%20Bolunmez\%20Butunlugu\%2006_2007.pdf. Alındığı Tarih: 29.04.2014.

Kirişçi, K. ve Winrow, G.M. (2011). Kürt sorunu: Kökeni ve gelişimi (Çev. A.Fethi). İstanbul: Tarih Vakfi Yurt Yayınlar1.

Konda (2011). Kürt meselesi'nde alg1 ve beklentiler araştırması bulgular raporu. Konda Araştırma ve Danışmanlık: http://www.konda.com.tr/tr/ raporlar.php.

Leyens, J. P., Paladino, P. M., Rodriguez, R. T., Vaes, J., Demoulin, S., Rodriguez, A. P. ve Gaunt, R. (2000). The emotional side of prejudice: The role of secondary emotions. Personality and Social PSychology Review, 4, 186-197.

Leyens, J. P., Rodriguez, A. P., Rodriguez, R. T., Gaunt, R., Paladino, P. M., Vaes, J. ve Demoulin, S. (2001). Psychological essentialism and the differential attribution of uniquely human emotions to ingroups and outgroups. European Journal of Social Psychology, 31, 395-411.

Leyens, J. P., Cortes, B., Demoulin, S., Dovidio, J. F., Fiske, S. T., Gaunt, R. Paladino, P. M., Rodriguez, A. P., Rodriguez, R. T. ve Vaes, J. (2003). Emotional prejudice, essentialism, and nationalism. European Journal of Social Psychology, 33, 703-717.

Leyens, J. P., Demoulin, S., Vaes, J., Gaunt, R. ve Paladino, M. P. (2007). Infra-humanisation: The wall of group differences. Social Issues and Policy Review, 1, 139-172.

Milliyet (4 Nisan 2013). İşte akil insanlar heyeti. http:// siyaset.milliyet.com.tr/iste-akil-insanlar-heyeti/ siyaset/siyasetdetay/04.04.2013/1689038/default. htm. Alındiğ 1 tarih 27.02.2014.

Nadler, A., Malloy, T. E. ve Fischer, J. D. (Ed.) (2008a). The social psychology of intergroup reconciliation. New York: Oxford University Press.

Nadler, A., Malloy, T. E. ve Fischer, J. D. (2008b). Intergroup reconciliation: Dimensions and themes. A. Nadler, T. Malloy ve J. D. Fisher (Ed.), The social psychology of intergroup reconciliation içinde (s. 3-12). New York: Oxford University Press.

Nadler, A. ve Saguy, T. (2004). Trust building and reconciliation between adversarial groups: A social psychological perspective. H. Langholtz ve C. E. Stout (Eds.), The Psychology of Diplomacy içinde (s. 29-46). New York: Praeger. 
Nadler, A. ve Shnabel, N. (2008). Instrumental and Socioemotional Paths to Intergroup Reconciliation and the Needs-Based Model of Socioemotional Reconciliation. A. Nadler, T. Malloy ve J. D. Fisher (Eds.), Social Psychology of Intergroup Reconciliation içinde (s. 37-56). Oxford: Oxford University Press.

Noor, M., Shnabel, N., Halabi, S., \& Nadler, A. (2012). When suffering begets suffering: The psychology of competitive victimhood between adversarial groups in violent conflicts. Personality \& Social Psychology Review, 16, 351-374.

Nunnally, J. C. ve Bernstein, I. H. (1994). Psychometric theory. New York: McGraw-Hill.

Paladino, P. M., Leyens, J. Ph., Rodriguez, R. T., Rodriguez, A. P., Gaunt, R. ve Demoulin, S. (2002). Differential association of uniquely and non-uniquely human emotions to the ingroup and the outgroups. Group Processes \& Intergroup Relations, 5, 105117.

Pereira, C., Vala, J. ve Leyens, J. P. (2009). From infrahumanization to discrimination: Mediation of symbolic threat needs egalitarian norms. Journal of Experimental Social Psychology, 45, 336-344.

Saraçoğlu, C. (2009). İzmirli orta sınıfta Kürt algısı: Mekân, sınıf ve kentsel yaşam. Praksis, 21, 17-46.

Seta (2013). Seta 2013 yili analizi: 2013'te Türkiye. Aralik, 2013, say1:74. Ankara: Seta. http:/file.setav. org/Files/Pdf/20140102151113_2013teturkiye_ pdf_4.pdf.

Shnabel, N. ve Nadler, A. (2008). A needs-based model of reconciliation: Satisfying the differential emotional needs of victim and perpetrator as a key to promoting reconciliation. Journal of Personality and Social Psychology, 94(1), 116-132. doi:10.1037/0022-3514.94.1.116.

Stein, N. L. ve Oatley, K. (1992). Basic emotions: Theory and measurement. Cognition and Emotion, 6(34), 161-168.

Tajfel, H. ve Turner, J. C. (1979). An integrative theory of inter-group conflict. W. G. Austin ve S. Worchel (Ed.) The social psychology of inter-group relations içinde (s. 33-47). T. Monterey: CA: Brooks/ Cole.

Tam, T., Hewstone, M., Cairns, E., Tausch, N., Maio, G. ve Kenworthy, J. (2007). The impact of intergroup emotions on forgiveness in Northern Ireland. Group processes \& Intergroup Relations, 10, 119-136.

Tam, T., Hewstone, M., Kenworthy, J. B., Cairns, E., Marinetti, C., Geddes, L. ve Parkinson, B. (2008). Postconflict reconciliation: Intergroup forgiveness and implicit biases in Northern Ireland. Journal of Social Issues, 64, 303-320. doi:10.1111/j.15404560.2008.00563.x.

T24 (13 Nisan 2013). Çözüm sürecine kim ne kadar destek veriyor? http://t24.com.tr/haber/cozum-surecine-kim-ne-kadar-destek-veriyor,227644. Alındığ 1 tarih: 01.05.2014.

Vaes, J., Leyens, J. P., Paladino, P. M. ve Miranda, M. P. (2012). We are human, they are not: Driving forces behind outgroup dehumanisation and the humanisation of the ingroup. European Review of Social Psychology, 23(1), 64-106. doi: 10.1080/10463283.2012.665250

Vaes, J, Paladino, M. P., Castelli, L., Leyens, J. P. ve Giovanazzi, A. (2003). On the behavioral consequences of infra-humanization: The implicit role of uniquely human emotions in intergroup relations. Journal of Personality and Social Psychology, 85, 1016-1034.

Vaes, J., Paladino, M. P. ve Leyens, J. P. (2002). The lost e-mail: Pro-social behaviour induced by uniquely human emotions. British Journal of Social Psychology, 41, 521-534.

Vaes, J., Paladino, M. P. ve Leyens, J. P. (2004). Perspective taking in an intergroup context and the use of uniquely human emotions: Drawing an E on your forehead. International Review of Social Psycho$\log y, 17,5-26$.

Vaes, J., Paladino, M. P. ve Leyens, J. P. (2006). Priming uniquely human emotions and the in-group (but not the out-group) activates humanity concepts. European Journal of Social Psychology, 36, 169-181.

Vaes, J., Paladino, M. P. ve Magagnotti, C. (2011). The human message in politics: The impact of emotional slogans on subtle conformity. Journal of Social Psychology, 151, 162-179. doi: 10.1080/00224540903510829

van Zomeren, M., Postmes, T. ve Spears, R. (2008). Toward an integrative social identity model of collective action: A quantitative research synthesis of three socio-psychological perspectives. Psychological Bulletin, 134, 504-535.

Wohl, M. J. A. ve Branscombe, N. R. (2005). Forgiveness and collective guilt assignment to historical groups depend on level of social category inclusiveness. Journal of Personality and Social Psychology, 88, 288-303. doi:10.1037/0022-3514.88.2.288

Wohl, M., Hornsey, M. ve Bennett, S. (2012). Why group apologies succeed and fail: Intergroup forgiveness and the role of primary and secondary emotions. Journal of Personality and Social Psychology, 102(2), 306-322. doi:10.1037/a0024838 


\section{Ek-1. Çalış̧malarda Kullanılan Barış Sürecini Destekleme Çağrısı Metni ve Bu Çağrı Öncesinde Verilen Yazılı Yönerge}

\section{Yönerge}

Aşağıda barış sürecine ilişkin bir çağrı metni yer almaktadır. Önce bu çağrı metninin kendisini Türk olarak tanımlayan bir kişi tarafından size hitaben yazıldığını düşününüz. Ardından bütün metni dikkatlice okuyunuz. (Koşul 1)

Aşağıda barış sürecine ilişkin bir çağrı metni yer almaktadır. Önce bu çağrı metninin kendisini Kürt olarak tanımlayan bir kişi tarafından size hitaben yazıldığını düşününüz. Ardından bütün metni dikkatlice okuyunuz. (Koşul 2)

\section{Barış Sürecini Destekleme Çağrısı Metni}

Merhaba,

Bildiğiniz gibi, Türkiye yaklaşık 30 yıldan bu yana devam eden bir şiddet ve çatışma ortamı içinde bulunmaktadır. Bu şiddet ve çatışma ortamı, toplumun değişik kurum ve kesimleri tarafından "Kürt sorunu”, "Güneydoğu sorunu”, "terör sorunu” gibi farklı isimlerle tanımlanmaktadır. Yaklaşık bir yıl önce hükümet tarafından bu şiddet ve çatışma ortamının son bulmasına yönelik 'barış süreci' olarak adlandırılan bir süreç başlatılmıştır.

Bir grup gönüllü olarak biz de, hükümetten bağımsız olarak bir dizi etkinlikte bulunarak barış sürecine katkıda bulunmak istiyoruz. Hükümetle ve herhangi bir siyasi grupla ilişkimizin olmadığını ve tek amacımızın Türkiye'nin kalıcı bir barıș ortamına kavuşması olduğunu bilmenizi isteriz. Siyasi görüşünüz ve inancınız ne olursa olsun yapacağımız çalışmalara vereceğiniz her türlü desteğe açı̆̆ız

En kısa zamanda sizi de aramızda görmek dileğiyle...

\section{Ek-2. İkinci Çalışmada Barış Sürecini Destekleme Çağrısına Eklenen Duygular ve Bu Duyguların İçinde Geçtiği Paragraflar}

1. Ben kendi adıma, bugüne kadar barışın sağlanması için gösterdiğim çabalardan dolayı büyük bir "haz duyuyorum" ve elimizdeki barış fırsatını kaçırmak istemeyen diğer insanlara kendimi "yakın hissediyorum” (pozitif birincil duygu koşulu).

2. Ben kendi adıma, bugüne kadar barışın sağlanması için yeterince çaba göstermemiş olmaktan dolayı büyük bir “üzüntü duyuyorum" ve elimizdeki barış firsatını kaçırmaktan "korkuyorum” (negatif birincil duygu koşulu).

3. Ben kendi adıma, bugüne kadar barışın sağlanması için gösterdiğim çabalardan dolayı büyük bir "gurur duyuyorum" ve elimizdeki barış firsatını kaçırmayacağımızı "umut ediyorum” (pozitif ikincil duygu koşulu).

4. Ben kendi adıma, bugüne kadar barışın sağlanması için yeterince çaba göstermemiş olmaktan dolayı büyük bir "hayal kırıklığı yaşıyorum" ve elimizdeki barış firsatını kaçırırsak barışın sağlanacağına ilişkin "inancımı yitireceğimi hissediyorum" (negatif ikincil duygu koşulu). 